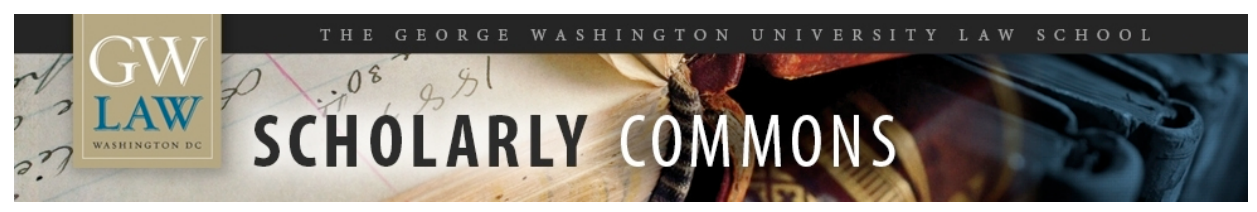

\title{
The Donor Class: Campaign Finance, Democracy, and Participation
}

\section{Spencer A. Overton}

George Washington University Law School, soverton@law.gwu.edu

Follow this and additional works at: https://scholarship.law.gwu.edu/faculty_publications

Part of the Law Commons

\section{Recommended Citation}

Spencer Overton, The Donor Class: Campaign Finance, Democracy, and Participation, 152 U. Pa. L. Rev. (2004).

This Article is brought to you for free and open access by the Faculty Scholarship at Scholarly Commons. It has been accepted for inclusion in GW Law Faculty Publications \& Other Works by an authorized administrator of Scholarly Commons. For more information, please contact spagel@law.gwu.edu. 


\section{THE DONOR CLASS: CAMPAIGN FINANCE, DEMOCRACY, AND PARTICIPATION}

\section{SPENCER OVERTON ${ }^{\dagger}$}

As a result of disparities in resources, a small, wealthy, and homogenous donor class makes large contributions that fund the bulk of American politics. Even in the aftermath of recent campaign reforms, the donor class effectively determines which candidates possess the resources to run viable campaigns. This reality undermines the democratic value of widespread participation. Instead of preventing "corruption" or equalizing funds between candidates, the primary goal of campaign reform should be to reduce the impact of wealth disparities and empower more citizens to participate in the funding of campaigns. On average, candidates should receive a larger percentage of their funds from a greater number of people in smaller contribution amounts. Reforms such as establishing matching funds and providing tax credits for smaller contributions, combined with emerging technology, would enable more Americans to make contributions and would enhance their voices in our democracy.

\section{INTRODUCTION}

Opponents of campaign finance reform embrace a relatively laissez-faire reliance on private markets to fund campaigns for public office. Although they champion the individual rights of those who con-

\footnotetext{
${ }^{\dagger}$ Associate Professor of Law, The George Washington University Law School. Michael Abramowicz, Mark Alexander, Brandon Briscoe, Kim Christensen, Richard Hasen, Adam Lioz, Ira Lupu, Leslie Overton, Josiah Slotnick, Dan Solove, and Fane Wolfer read earlier drafts of this Article and provided helpful comments. Clyde Wilcox graciously shared demographic data about contributors to presidential primary candidates during the 2000 election cycle. In addition to participants in the University of Pennsylvania Law of Democracy symposium, participants in law faculty workshops at Fordham, Hofstra, and Washington \& Lee, the Equal Justice in the West Conference at the University of Nevada Las Vegas Law School, and the lecture series of the American Constitution Society at the University of Chicago Law School provided valuable observations and suggestions. This Article also benefited from exchanges with Edwin Baker, Rick Banks, John Bonifaz, Paul Butler, Anupam Chander, Elizabeth Garrett, Heather Gerken, Paul Herrnson, Jamahl Johnson, Orin Kerr, Sheila Krumholz, Kenneth Mack, Michael Malbin, Joe McLean, Frank Michelman, Martha Minow, Lawrence E. Mitchell, Larry Noble, Nick Nyhart, Nathaniel Persily, Chellie Pingree, Joshua Rothstein, Glen Shor, Jonathan Siegel, Donald Simon, Joe Singer, Bradley Smith, Dalia Tsuk, and Cherrie-Ann Walters. Ian Bassin provided invaluable research assistance and feedback. This article is dedicated to the memory of Randall Merritt.
} 
trol resources, antireformers largely overlook the structural impact of vast disparities in wealth on the ability of most citizens to make financial contributions. ${ }^{1}$

This Article uses the Supreme Court's recent opinion in McConnell v. $F E C^{2}$ to argue that the law should play a central role in reducing the impact of disparities in wealth on political participation. McConnell upheld large parts of the Bipartisan Campaign Reform Act of 2002 $(\mathrm{BCRA})^{3}$ - a regulatory overhaul that banned unlimited soft money contributions and restricted corporate and union spending on political campaigns. In so doing, the Court in McConnell acknowledged the adverse impact that concentrated wealth has on widespread democratic participation and self-government. ${ }^{4}$ In the aftermath of the reforms upheld in McConnell, however, disparities in wealth continue to affect participation.

A relatively small and wealthy group of individuals-the "donor class"-gives large hard money ${ }^{5}$ contributions that fund the bulk of

${ }^{1}$ See, e.g., Lillian BeVier, Campaign Finance Regulation: Less, Please, 34 ARIZ. ST. L.J. 1115,1118 (2002) (arguing that disparities in wealth do not make the case for regulating independent expenditures for election-related speech because many other sources of unequal political influence will remain); Bradley A. Smith, Faulty Assumptions and Undemocratic Consequences of Campaign Finance Reform, 105 YALE L.J. 1049, 1056 (1996) (indicating the author's opposition to the belief "that modern campaigns have been corrupted by big money"); cf. Buckley v. Valeo, 424 U.S. 1, 48-49 (1976) (per curiam) (invalidating spending limits and reasoning that "the concept that government may restrict the speech of some elements of our society in order to enhance the relative voice of others is wholly foreign to the First Amendment").

${ }^{2} 540$ U.S. 93, 124 S. Ct. 619 (2003).

${ }^{3}$ Bipartisan Campaign Reform Act of 2002 (BCRA), Pub. L. No. 107-155, 116 Stat. 81 (codified in scattered sections of 2, 18, 28, 36, 47 U.S.C.).

${ }^{4}$ See infra Part I.B. for a discussion of the reasoning of McConnell.

${ }^{5}$ Money that is subject to the Federal Election Campaign Act's disclosure requirements and source and amount limitations is known as "hard" or "federal" money. See McConnell, 124 S. Ct. at 648-49 (explaining that contributions made with funds subject to the Federal Election Campaign Act's requirements and limitations are called "federal" or "hard" money, whereas contributions intended to influence elections and made with funds not subject to the Act are called "nonfederal" or "soft" money). While BCRA banned unlimited "soft" or "nonfederal" money contributions to federal parties (money previously not subject to regulation by the Federal Election Campaign Act), the law increased the amount of "hard money" an individual may contribute to a federal candidate from $\$ 1000$ to $\$ 2000$, and it increased the annual aggregate amount of hard money an individual may give to candidates, PACs, and parties from $\$ 25,000$ to $\$ 95,000$. BCRA, Pub. L. No. 107-155, secs. 101, 307, $\$ \S 315$, 323, 116 Stat. 81, 82, 10203 (2002). Even before BCRA restricted soft money and increased the hard money limits, hard money was the primary source of candidate and party funding. See PuB. CAMPAIGN, HARD FACTS ON HARD MONEY (2001), at http://www.publicampaign.org/ publications/studies/hardfacts/hardfactsfull.htm (last visited Aug. 28, 2004) ("Hard money remained the dominant source of campaign funding in the 2000 election cycle 
American politics. ${ }^{6} \quad$ Although approximately $51.3 \%$ of voting-age Americans cast a ballot in the 2000 general presidential election, ${ }^{7}$ less than $2 \%$ contributed $\$ 200$ or more to a presidential or congressional candidate. ${ }^{8}$ In the 2003-2004 election cycle, contributions of between

outweighing party soft money by a ratio of 4.4 to $1 . ”)$.

${ }^{6}$ See Bob Herbert, Editorial, The Donor Class, N.Y. Times, July 19, 1998, at 15 ("I doubt that many people are aware of just how elite and homogenous the donor class [to political campaigns] is. It's a tiny group-just one-quarter of 1 percent of the population-and it is not representative of the rest of the nation."). For the purposes of this Article, the donor class consists of natural persons who have made at least one contribution over $\$ 200$ to a federal candidate, party, or PAC within the last two election cycles.

7 See Fed. Election Comm'n, Voter Registration And Turnout 2000, at http://www.fec.gov/pages/2000turnout/reg\&to00.htm (last visited Sept. 13, 2004) (reporting that official turnout for the 2000 presidential election was $105,586,274$ voters, or $51.3 \%$ of the voting-age population).

${ }^{8}$ Anne Gearan, Supreme Court Eyes Campaign Finance Laws, Associated Press, Sept. 5, 2003, available at $2003 \mathrm{WL} 63458717$. The precise percentage of voting-age Americans who contributed to a federal candidate, PAC, or party is not ascertainable because the FEC requires recipients to report only donations of more than $\$ 200$ in an itemized report of any detail. See 28 U.S.C. $\$ 434$ (b), (e) (2000) (requiring identification of each person who makes a contribution or contributions with an aggregate value exceeding $\$ 200$ per year, but allowing recipients to report lesser contributions at their discretion). The recipient combines all contributions of $\$ 200$ or less and reports them as one total. Nevertheless, the numbers show that a small class of Americans gives most of the money collected by federal candidates, parties, and PACs. In the 2001-2002 election cycle, only $0.22 \%$ of the voting-age population in the United States gave a contribution over $\$ 200$ to a federal congressional candidate, party, or PAC, and this group accounted for $76 \%$ of the funds given to federal candidates by individuals. ADAM LIOZ \& Alison Cassady, U.S. Pub. InTERest Research Group, The Role of Money in the 2002 CONGRESSIONAL ELECTIONS 4 (2003).

Some might assert that the distribution of wealth does not have an adverse impact on democratic participation because union PACs are funded by deductions from the dues of millions of union members. Although this is an important point, unions do not facilitate the political participation of most Americans. Less than $6 \%$ (just under sixteen million) are members of a union, see U.S. CENSUS BUREAU, STATISTICAL AbSTRACT OF THE UNited STATES: 2003, at 432 tbl.658 (123d ed. 2003), available at http://www.census.gov/prod/2004pubs/03statab/labor.pdf, and not all of these individuals contribute to a union PAC, see 11 C.F.R. § 114.5(a) (2004) (authorizing a union member to request that the union not use her dues to support political causes). Union PACs gave about $\$ 52.6$ million to federal candidates in the 2000 election cycle, or about $3.7 \%$ of the total $\$ 1.423$ billion collected. See 2000 Presidential Race: Total Raised and Spent, Ctr. for Responsive Politics (n.d.), at http://www.opensecrets.org/ 2000elect/index/AllCands.htm (last visited Sept. 15, 2004) (indicating that U.S. presidential candidates collected $\$ 375.3$ million during the 2000 election cycle); Labor: PAC Contributions to Federal Candidates 1999-2000, Ctr. for Responsive Politics (n.d.), at http:/ / www.opensecrets.org/pacs/sector.asp?txt=P01\&cycle=2000 (last visited Sept. 15,2004 ) (indicating union PACs gave $\$ 52.6$ million to federal candidates during the 2000 election cycle); The Big Picture, 2000 Cycle, The Price of Admission, Ctr. for Responsive Politics (n.d.), at http://www.opensecrets.org/bigpicture/stats.asp?cycle=2000\& type $=A \&$ display $=\mathrm{T}$ (last visited Sept. 15, 2004) (indicating that U.S. Senate candidates 
$\$ 200$ and $\$ 2000$ represented $69 \%$ of the money individuals donated to Republican President George W. Bush and 63\% of such money donated to Democratic presidential nominee John Kerry. ${ }^{9}$

Access to financial resources rather than mere political interest defines the donor class. ${ }^{10}$ While only $13.4 \%$ of American households earned at least $\$ 100,000$ in $2000,{ }^{11}$ these households gave $85.7 \%$ of contributions over $\$ 200$ collected by presidential candidates. ${ }^{12}$

The problem with money in politics is not simply that a handful of individuals made $\$ 1$ million soft money contributions, but also that relatively few Americans control enough wealth to make contributions of between $\$ 200$ and $\$ 2000$ consistently and comfortably. ${ }^{13}$ Despite

collected $\$ 447.9$ million and U.S. House candidates collected $\$ 600.3$ million during the 2000 election cycle).

${ }^{9}$ Press Release, Campaign Fin. Inst., at tbl.3 (Oct. 4, 2004), avaialable at http:// www.cfinst.org/pr/100404_Table3.pdf (last visited Oct. 8, 2004). Contributions of $\$ 1000$ or more represented $57 \%$ of the funds given by individuals to Bush and $44 \%$ of the money given to Kerry. Id.

${ }^{10}$ See Henry E. Brady et al., Beyond SES: A Resource Model of Political Participation, 89 AM. POL. SCI. REV. 271, 283 (1995) ("The results are unambiguous: the major determinant of giving money is having money. Years of education also matter, but neither free time nor civic skills affect monetary contributions." (citation omitted)); E-mail from Clyde Wilcox, Professor of Government, Georgetown University, to Spencer Overton, Associate Professor of Law, The George Washington University Law School (July 3, 2004, 12:51:29 EST) (on file with author) [hereinafter Wilcox July 3, 2004 Chart] (indicating that while individuals with family incomes of less than $\$ 100,000$ accounted for only $14.3 \%$ of contributions over $\$ 200$, they accounted for $73.5 \%$ of contributions of $\$ 100$ and less).

${ }^{11}$ Carmen DeNavas-Walt ET AL., U.S. Census Bureau, MONEY InCOME IN THE UNITED STATES: 2000, at 17 tbl.A-1 (2001), available at http://www.census.gov/prod/ 2001pubs/p60-213.pdf (last visited Sept. 15, 2004).

${ }^{12}$ See Wilcox July 3, 2004 Chart, supra note 10 (indicating that of presidential primary donors in the 2000 election, individuals with family incomes of $\$ 100,000$ or more accounted for $85.7 \%$ of individual contributors of over $\$ 200$ and $93.3 \%$ of individual contributors of $\$ 1000)$. The demographic data Professor Wilcox provided for this Article is based on a survey of 2881 donors, selected randomly, to presidential primary candidates for the 2000 elections. The study was organized and managed by Professor Wilcox and several of his colleagues. See Clyde Wilcox et al., With Limits Raised, Who Will Give More? The Impact of BCRA on Individual Donors, in LIFE AFTER REFORM: WHEN the Bipartisan Campaign Reform Act Meets Politics 61, 64-65 (Michael J. Malbin ed., 2003) (explaining the methodology of their study of donors to 2000 presidential primary candidates); see also Peter Francia et al., Donor Dissent: Congressional Contributors Rethink Giving, PuB. PERSP. July/Aug. 2000, at 29-30 (revealing that $78 \%$ of donors to congressional candidates during the 1996 election cycle had household incomes over $\$ 100,000)$

${ }^{13}$ The wealthiest fifth of U.S. households controls over $79 \%$ of the nation's wealth, whereas the bottom two-fifths controls just over $1 \%$. See Javier Díaz-Giménez et al., Dimensions of Inequality: Facts on the U.S. Distributions of Earnings, Income, and Wealth, FED. Res. BANK OF MinNeAPOlis Q. REV., Spring 1997, at 3, 13 tbl.6 (listing the wealth 
the reluctance of antireformers to grapple with disparities in financial resources among individuals, the law's conception of distribution matters.

Prior to McConnell, a handful of reformers envisioned wealth as one of the principal problems, but their focus on formal equality ${ }^{14}$ had shortcomings. Granted, adopting equality as the goal provided a normative baseline, and it allowed the reformers to overcome uninspiring regulatory detail by invoking civil rights analogies. By focusing on formal equality, however, the reformers selected an unattainable ideal. A newspaper editorial endorsing one of the candidates, for example, could throw off precise equality. In addition, by pushing for equal public funding paid directly to candidates, some egalitarian reformers disregarded the central role that citizens should play in democratic debate. ${ }^{15}$ The rigid positions embraced by antireformers and egalitarians framed the debate as a stark choice between unrestrained liberty and uniform equality.

The focus on these polar extremes detracts from a pressing problem that persists in the aftermath of BCRA. Massive disparities in the distribution of wealth cause disparities in political participation. The donor class effectively selects which candidates will be viable through large hard money contributions.

controlled by the lowest through highest quintiles, respectively, as $-0.39,1.74,5.72$, 13.43, and 79.49).

${ }^{14}$ See, e.g., Edward B. Foley, Equal-Dollars-Per-Voter: A Constitutional Principle of Campaign Finance, 94 COLUM. L. REv. 1204, 1215 (1994) ("In thinking about distributive justice, I start with the basic premise that all persons have equal intrinsic worth, which I call the principle of intrinsic equality."); Richard L. Hasen, Clipping Coupons for Democracy: An Egalitarian/Public Choice Defense of Campaign Finance Vouchers, 84 CAL. L. REV. 1, 27-28 (1996) (asserting that "[e]galitarian pluralism aims to equalize the ability of different individuals to affect the political process" and is based on the notion that "disparities in wealth and ability to organize are not relevant to the individual's right to influence political outcomes"); Jamin Raskin \& John Bonifaz, Equal Protection and the Wealth Primary, 11 YALE L. \& POL'Y REv. 273, 279 (1993) (declaring that "[t] he purpose of this Article is to demonstrate that the current campaign finance regime is inconsistent with equal protection or, at the very least, warrants congressional action to vindicate equal protection").

${ }^{15}$ This Article uses the terms "citizen" and "American" to refer to all natural persons, including certain immigrants, eligible to make financial contributions to candidates under federal law. See FED. EleCtion COMm'N, CAMPAign Guide For CONGRESSIONAL CANDIDATES AND COMMITTEES 28 (2004) (stating that although contributions by foreign nationals are prohibited, an "immigrant is eligible to make a contribution if the immigrant has a 'green card' indicating that he or she is lawfully admitted for permanent residence in the United States"), available at http://www.fec.gov/ finance_law.html. 
Part I of this Article reviews two opposing approaches that have emerged in the law. The class-blind approach minimizes the significance of disparities in wealth and forms the basis of the arguments of many scholars, politicians, and judges who oppose campaign reform. In contrast, the class-sensitive vision highlights disparities in access to resources as a central issue in lawmaking; this approach motivated the Court in McConnell to tolerate restrictions on soft money contributions and corporate spending. Part II examines and reveals the many shortcomings of the antireformers' assertion that the impact of wealth on democratic participation warrants minimal concern. To reduce the impact of disparities in resources and broaden participation beyond the donor class, Part III proposes a goal that candidates, parties, and political action committees (PACs) receive a much larger percentage of their funds from contributors of $\$ 100$ or less. Part III also predicts that matching funds and tax credits for smaller contributions, combined with innovative use of emerging technology, would move our political process closer to that objective.

\section{Class-Blind and Class-Sensitive Approaches to LAW}

Commentators have recognized that legal decisions are influenced by the particular theoretical approach of the decision maker, which is in turn influenced by certain basic assumptions, beliefs, and commitments. ${ }^{16}$ This Part focuses on two different approaches to lawmaking: the class-blind approach fails to recognize the significance of disparities in wealth, while the class-sensitive vision is cognizant of such issues.

\section{A. The Class-Blind Approach: Lawmaking That Ignores Disparities in Wealth}

The class-blind approach to law discourages consideration of relative differences in wealth among individuals. The approach accepts such disparities as an inevitable reality that rarely warrants government intervention. Under this vision, individual citizens are responsible for securing the resources required or meeting the conditions necessary to satisfy their wants and needs.

\footnotetext{
${ }^{16}$ See generally Gerald B. Wetlaufer, Systems of Belief in Modern American Law: A View From Century's End, 49 AM. U. L. REV. 1, 3 (1999) (asserting that disagreements about rules, doctrine, and policy often arise from six discrete systems of belief, and that these different beliefs stem from different assumptions, beliefs, and commitments regarding the world).
} 
Advocates of the class-blind approach do not regard their indifference to wealth disparities as callousness, but rather as objectivity that enhances the quality and credibility of decision making. Conscious accounting of disparities in wealth, the argument goes, will most likely result in class-based factions. Ambitious politicians tend to use the divisive rhetoric of class warfare not to enhance fairness for those with fewer resources, but as an instrument to satisfy their personal hunger for political power. ${ }^{17}$ The resentment, discontent, and hostility that arise threaten the stability of economic markets as well as government.

Advocates of the class-blind approach harbor a strong commitment to private property, to the priority of private interests over public interests, and to bright-line rules and concepts over more nuanced balancing and compromise. ${ }^{18}$ The schools of legal and political thought that lean more toward a class-blind vision include classical formalism associated with the Lochner decision, ${ }^{19}$ law and economics, public choice theory, and libertarianism. ${ }^{20}$

${ }^{17}$ This resembles James Madison's concern that if the law fails to protect private property from political redistribution, the propertyless might "unite against the propertied" and "become the 'dupes and instruments of ambition." JENNIFER NEDELSKY, PRIVATE PROPERTY AND THE LIMITS OF AMERICAN CONSTITUTIONALISM: THE MADISONIAN FRAMEWORK AND ITS LEGACY 27-28 (1990) (quoting James Madison, Observations on Jeffersons's Draft of a Constitution for Virginia (Oct. 15, 1788), reprinted in 1 The FoundeR's Constitution 649, 650 (Philip B. Kurland \& Ralph Lerner eds., 1987)).

${ }^{18}$ Cf. Wetlaufer, supra note 16, at 13-14 (describing academic formalists, who typically lean toward class-blind visions, as possessing "a commitment to the rights of private property, the freedom and sanctity of contract, the priority of private over public interests, and a resistance to legislative reform").

${ }^{19}$ Lochner v. New York, 198 U.S. 45, 57-58 (1905) (reasoning that an individual's right to enter into contracts was protected by the Fourteenth Amendment's Due Process Clause and was generally immune from interference by the state).

${ }^{20}$ While writers skeptical of legal intervention that alters market distribution dominate classical formalism, law and economics, and public choice, nothing inherent in these movements makes them class-blind. One could argue, for example, that legal intervention that ensures broad-based distribution of goods like quality public education to the poor advances the law and economics goal of wealth maximization. See AMARTYA SEN, DEVELOPMENT AS FREEDOM 128-29 (1999) (noting that public goods, "which people consume together rather than separately," may have a significant influence on our welfare, thus "[e]fficiency considerations ... supplement the argument for equity in supporting public assistance in providing basic education, health facilities, and other public (or semipublic) goods"); see also LOUIS KAPLOW \& STEVEN SHAVELL, FAIRNESS VERSUS WELFARE 5, 29 n.26 (2002) (refuting the "common understanding of normative economic analysis, whereby legal rules are assessed by reference to wealth maximization or efficiency, criteria that many construe... as ignoring distributive concerns" and the statements by "[s]ome law and economics scholars . . that distribution ought not to matter in principle"). 
In the campaign finance context, class-blind themes abound, especially among those opposed to regulation. Just as less wealthy individuals should not suffer discrimination because they cannot afford to pay a poll tax, wealthier individuals should not face discrimination because they can afford to contribute and spend more. ${ }^{21}$ Antireformers do not see contribution and spending restrictions as "content neutral," but as measures designed to suppress the views of wealthier individuals. Bradley Smith, a leading antireformer, illustrates the point with the following question: "[A]re all individuals treated with equal concern and respect when they are not allowed to equally employ the fruits of their labors and talents to political action?",22

One strain of the Supreme Court's campaign finance decisions rejects the argument that individual contributions and expenditures must be restricted to reduce affluent persons' influence and enhance the relative ability of the less wealthy to affect elections. The Court in Buckley $v$. Valeo reasoned that "the concept that government may restrict the speech of some elements of our society in order to enhance the relative voice of others is wholly foreign to the First Amendment ...." Instead of acknowledging disparities in wealth distribution among citizens, the Court justified contribution limits by focusing on the potentially corrupting impact of large contributions on elected officials. $^{24}$

According to the class-blind assumptions about political participation underlying Buckley and its progeny, the private economic market determines the allocation of entitlements to financial resources for

${ }^{21}$ Cf. Buckley v. Valeo, 424 U.S. 1, 49 (1976) (per curiam) ("The First Amendment's protection against governmental abridgment of free expression cannot properly be made to depend on a person's financial ability to engage in public discussion.”); Kathleen M. Sullivan, Discrimination, Distribution and Free Speech, 37 ARIZ. L. REV. 439, 440 (1995) ("[T] he Court has extended the free speech principle to protect the speech rights of the wealthy.”).

${ }^{22}$ Bradley A. Smith, The Sirens' Song: Campaign Finance Regulation and the First Amendment, 6 J.L. \& POL'Y 1, 40 (1997). Professor Smith became Chairman of the Federal Election Commission on January 1, 2004. For a discussion of the Chairman's appointment and first weeks in office, see Thomas B. Edsall, McCain-Feingold Unmade? New Election Regulator Opposes Campaign Finance Law, WASH. POST, Feb. 5, 2004, at A19.

${ }^{23}$ Buckley, 424 U.S. at 48-49.

${ }^{24}$ The Court in Buckley struck down spending limits, however, concluding that independent expenditures do "not presently appear to pose dangers of real or apparent corruption comparable to those identified with large campaign contributions." Id. at 46. 
use in the political sphere. ${ }^{25}$ The donor class is a natural product of the market and requires no legal acknowledgment or remedy. ${ }^{26}$

\section{B. The Class-Sensitive Approach: McConnell v. FEC and Lawmaking That Considers Disparities}

In contrast to the class-blind vision of law, the class-sensitive vision recognizes and sometimes seeks to remedy disparities in private property ownership. Those sensitive to class believe that taking economic disparities into account furthers understanding of the consequences of government action or inaction in particular contexts.

The class-sensitive vision is not socialist-it acknowledges that economic markets featuring private property generally serve important functions. A primary role of law, however, is to advance critical values that private markets either ignore or undermine. ${ }^{27}$ These values may be advanced through a variety of methods, including restrictions on activities, financial subsidies, and varying tax burdens and incentives. Although this Article focuses on the campaign finance context, the class-sensitive approach is useful in judicial interpretation and lawmaking in areas as diverse as tax policy, tort reform, contract

${ }^{25}$ See generally Lillian R. BeVier, What Ails Us?, 112 YALE L.J. 1135 (2003) (reviewing Bruce ACKerman \& IAN Ayres, Voting With Dollars: A NeW PARAdigm for CAMPAIGN FinANCE (2002)) (criticizing a public financing program, proposed by Bruce Ackerman and Ian Ayres, for its failure to consider market realities); Bradley A. Smith, Some Problems With Taxpayer-Funded Political Campaigns, 148 U. PA. L. REV. 591, 610-16 (1999) (encouraging acceptance of monetary inequality as a natural phenomenon that leads to no political inequality).

${ }^{26}$ Cf. Smith, supra note 1, at 1056 ("For most voters, familiarizing themselves with the candidates and voting in elections have always been the extent of their political involvement. Thus, for over 200 years, candidates have relied on a small base of donors who hoped to benefit directly from their preferred candidates' elections, whether through a public appointment or a higher tariff.").

Although class-blind advocates reject the use of law to address distributional concerns, some would employ law to correct rent-seeking market imperfections that are unrelated to disparities in the distribution of wealth, such as bribery and quid pro quo corruption. Cf. Owen M. Fiss, The Death of the Law?, 72 CORNELL L. REv. 1, 6-7 (1986) (describing the purposes of the law under law and economics as "provid[ing] the conditions necessary for effective bargaining [through] demarcating property rights, assuring bargains are enforced, [etc.]" and then functioning "only when bargaining breaks down or is not possible").

${ }^{27}$ Cf. State v. Shack, 277 A.2d 369, 372 (N.J. 1971) ("Property rights serve human values. They are recognized to that end, and are limited by it."); Dalia Tsuk, Corporations Without Labor: The Politics of Progressive Corporate Law, 151 U. PA. L. REV. 1861, 1882-1909 (2003) (discussing different attempts throughout the twentieth century to use corporate law to balance private interests and social welfare in a class-sensitive manner). 
interpretation, consumer protection, trusts and estates, class action procedure, education, health care, housing, and race relations. ${ }^{28}$

Although the drafters of BCRA aimed to prevent the corruption of politics rather than to correct disparities in wealth, the Supreme Court in McConnell acknowledged disparities in resources in its reasoning upholding the statute. Describing McConnell as the height of class-sensitive theory in the campaign finance context would be an overstatement. Nevertheless, certain passages in the opinion illustrate the Court's rejection of the class-blind approach found in Buckley.

For example, the Court employed a participatory self-government rationale in upholding the ban on unlimited soft money contributions, ${ }^{29}$ effectively suggesting that large contributions from a narrow group of wealthy donors threaten democratic participation by less wealthy citizens.

The Court noted that justifications for campaign restrictions were not limited to preventing quid pro quo corruption, but also included preventing "undue influence on an officeholder's judgment and the appearance of such influence." ${ }^{, 0}$ A real danger exists that officeholders will decide issues based not on the "merits" or the "desires of their constituencies," "but according to the wishes of those who have made large financial contributions valued by the officeholder." ${ }^{31}$ The Court

28 See, e.g., Turner Broad. Sys. v. FCC, 520 U.S. 180, 222 (1997) (suggesting that Congress could consider the wealth disparity between a media giant and a small independent broadcast station in enacting legislation to curb anticompetitive conduct); Clark v. Cmty. for Creative Non-Violence, 468 U.S. 288, 314 (1984) (Marshall, J., dissenting) (identifying class-sensitive applications of the First Amendment). But see In re Paoli R.R. Yard PCB Litig., 221 F.3d 449, 468 (3d Cir. 2000) (dismissing wealth disparity as a significant factor in distributing the costs of litigation); Williams v. Page, $309 \mathrm{~F}$. Supp. 814, 816 (N.D. Ill. 1970) ("[O]nly when the most fundamental rights are impinged upon will the court overturn an otherwise reasonable and equitable procedure which because of the disparity of wealth works a hardship on the poor.").

29 See Richard L. Hasen, Buckley is Dead, Long Live Buckley: The New Campaign Finance Incoherence of McConnell v. Federal Election Commission, 153 U. PA. L. REV. 31, 33 (2004) (describing the reasoning suggested by McConnell and explicitly articulated by Justice Breyer in other contexts as a "participatory self-government rationale.").

${ }^{30}$ McConnell v. FEC, 124 S. Ct. 619, 664 (2003) ("More importantly, plaintiffs conceive of corruption too narrowly. Our cases have firmly established that Congress' legitimate interest extends beyond preventing simple cash-for-votes corruption to curbing 'undue influence on an officeholder's judgment, and the appearance of such influence." (quoting FEC v. Colo. Republican Fed. Campaign Comm'n, 533 U.S. 431, $441(2001)))$.

${ }^{31} I d$. at 666 . Indeed, the Court expressed concerns about aggregations of wealth in the first line of the McConnell opinion, recalling that more than a century earlier reformers proposed legislation to prevent corporations from using their wealth to elect officials who would support the corporation's self interest "as against [the interests] of 
found that contribution limits "require candidates and political committees to raise funds from a greater number of persons" and "tangibly benefit public participation in political debate." ${ }^{32}$ The aim of this participatory self-government objective, elaborated by Justice Breyer in an earlier writing, is "to democratize the influence that money can bring to bear upon the electoral process, thereby building public confidence in that process, broadening the base of a candidate's meaningful support, and encouraging greater public participation." ${ }^{33}$

The Court in McConnell also acknowledged the impact that concentrated wealth can have by upholding the restrictions regarding corporate spending on advertisements that refer to a federal candidate and are broadcast just before an election. ${ }^{34}$ The Court quoted

the public." Id. at 644 (quoting United States v. Automobile Workers, 352 U.S. 567, 571 (1957) (quoting E. RoOT, ADDRESSES ON GOVERnMENT AND CiTIZENSHIP 143 (Robert Bacon \& James Brown Scott eds. 1916))).

${ }^{32} I d$. at 656 . The Court also recognized that disparities in wealth may suppress widespread participation in explaining that preventing "the appearance of corruption" is a rationale for upholding campaign restrictions. See Nixon v. Shrink Mo. Gov't PAC, 528 U.S. 377, 390 (2000) (stating that preventing the appearance of corruption was important because "the cynical assumption that large donors call the tune could jeopardize the willingness of voters to take part in democratic governance").

33 Stephen Breyer, Our Democratic Constitution, 77 N.Y.U. L. REv. 245, 253 (2002); see also Shrink Missouri, 528 U.S. at 401 (Breyer, J., concurring) (writing that campaign finance restrictions seek to "build public confidence in [the electoral] process and broaden the base of a candidate's meaningful financial support, encouraging the public participation and open discussion that the First Amendment itself presupposes" (citing Alexander Meiklejohn, Free Speech and Its Relation to SelfGOVERnMENT 24-27 (1948))). Perhaps the Court in McConnell did not elaborate on the participatory self-government rationale because one or two of the Justices are unprepared to explicitly embrace the rationale. See Hasen, supra note 29, at 32 (asserting that the Court "has continued to entertain the fiction that it is adhering to the anticorruption rationale of Buckley $v$. Valeo, perhaps because one or two members of the fiveJustice majority making the shift in McConnell may be unwilling (at least now) to expressly embrace Justice Breyer's participatory self-government rationale" (footnote omitted)); Spencer Overton, Restraint and Responsibility: Judicial Review of Campaign Reform, 61 WASH. \& LEE L. REV. 663, 684 (2004) (suggesting that perhaps the reasoning behind the Court's opinion in McConnell was sparse because the Justices in the majority agreed that specific provisions of BCRA should be upheld but "did not want to highlight the divisions in their reasoning"). See generally Cass R. Sunstein, Incompletely Theorized Agreements, 108 HARV. L. REV. 1733, 1737 (1995) ("When the convergence on particular outcomes is incompletely theorized, it is because the relevant actors are clear on the result without being clear, either in their own minds or on paper, on the most general theory that accounts for it.").

${ }^{34}$ The Act prohibits corporations and unions from spending money from their general treasuries on electioneering communications. See BCRA, Pub. L. No. 107-155, sec. 203, § 316(b) (2), 116 Stat. 81, 91-92 (2002). The statute constructively defines "electioneering communications" to consist of (1) any television, radio, cable, or satellite broadcast, (2) that refers to a clearly identified candidate for federal office, (3) run 
language from Austin v. Michigan Chamber of Commerce explaining that corporate spending restrictions are necessary due to "the corrosive and distorting effects of immense aggregations of wealth that are accumulated with the help of the corporate form and that have little or no correlation to the public's support for the corporation's political ideas. ${ }^{, 35}$ In Austin, the Court reasoned that special, state-created advantages, such as perpetual life and favorable treatment in accumulating and distributing assets, permit corporations to use "resources amassed in the economic marketplace"" to obtain an "unfair advantage in the political marketplace."

By stating that contribution limits enhance widespread participation and by embracing Austin's language, the Court in McConnell rejected the leading class-blind rationale that political money is speech. Whereas it is not "undue" for people to speak as much as they desire, aggregations of wealth can unfairly influence the political process. ${ }^{37}$ The danger is not the content of any speech or even the amount of speech produced, but instead the use of aggregations of wealth to gain political advantage or access. Influence that stems from large aggregations of wealth may be deemed "undue," such a rationale suggests, because most citizens do not have access to those massive quantities of wealth. Victors in economic markets need not enjoy unlimited advantages in

within 60 days before a general election or 30 days before a primary election, and (4) that can be received by at least 50,000 people in the district that the federal candidate seeks to represent. See id. sec. 201, § 304, 116 Stat. at 89-90.

${ }^{35}$ McConnell, 124 S. Ct. at 695-96 (quoting Austin v. Mich. Chamber of Commerce, 494 U.S. 652, 660 (1990)).

${ }^{36}$ Austin, 494 U.S. at 658-59 (quoting FEC v. Mass. Citizens for Life, Inc., 479 U.S. 238, 257 (1986)); see also FEC v. Beaumont, 539 U.S. 146, 153 (2003) (quoting Austin, 494 U.S. at 658-59). In a precursor to Austin, the Court stated that restrictions on business corporations reflect concern not simply about "use of the corporate form per se, but about the potential for unfair deployment of wealth for political purposes." Mass. Citizens for Life, Inc., 479 U.S. at 259.

${ }^{37}$ In upholding spending restrictions on corporations, the Austin opinion focused on the special state-created advantages given to corporations in accumulating wealth. Austin, 494 U.S. at 659 ("These state-created advantages not only allow corporations to play a dominant role in the Nation's economy, but also permit them to use 'resources amassed in the economic marketplace' to obtain 'an unfair advantage in the political marketplace."” (quoting Mass. Citizens for Life, 479 U.S. at 257 (1986)). McConnell employed the same rationale to uphold restrictions on corporate electioneering spending and expanded the rationale to uphold restrictions on union electioneering spending. Although one could assert that many individuals enjoy state-created advantages in accumulating wealth, the important lesson of McConnell is not that the case allows for spending restrictions on all individuals and entities. Rather, the case illustrates the Court's acknowledgment of the relationship between disparities in resources and democratic participation. 
the political sphere. Congress may embrace democratic norms that it base its actions not on the dictates of the donor class, but on the merits and the desires of most Americans. ${ }^{38}$

One should not overstate the holding of McConnell. The opinion does not explicitly sanction very low contribution limits, limits on spending by individuals and candidates, or limits on financial support of ballot initiatives. At the same time, however, the Court's holding acknowledges that massive disparities in wealth interfere with widespread democratic participation, thereby deflating the class-blind political rhetoric that money is speech. As a result, McConnell has the potential to shift the terms of the campaign reform debate toward a core problem: disparities in political participation caused by massive disparities in the distribution of wealth.

\section{Class-Blind ANTIREFormers OVERLOOK Distinct DEMOCRATIC VALUES AND OBJECTIVES}

This Part builds on McConnell's acknowledgment of disparities in wealth and challenges antireformers' justifications for largely disregarding such issues. The antireformers assert that money has little impact on political outcomes, that the fluid American economy gives all a fair opportunity to acquire resources, and that money is no different from other political tools like speaking ability or personal magnetism. This Part addresses these claims and concludes that the impact the distribution of financial resources has on political participation warrants concern.

${ }^{38}$ Although class-blind advocates are often antireformers, the class-sensitive approach does not always favor regulation. In FEC v. National Conservative PAC, 470 U.S. 480 (1985), the Court struck down a provision that limited PAC spending in support of presidential candidates who accept public financing. In striking the restriction, the Court noted that it was "significant that" about 101,000 people contributed an average of $\$ 75$ each to one PAC and about 100,000 contributed an average of $\$ 25$ each to another PAC. Id. at 494. To restrict expenditures that result from pooled resources, according to the Court, "would subordinate the voices of those of modest means as opposed to those sufficiently wealthy to be able to buy expensive media ads with their own resources." Id. at 495. 


\section{A. The Impact of Wealth on Those Who Lack Resources}

\section{The Importance of Money in Politics ${ }^{39}$}

Antireformers downplay the significance of disparities in wealth by asserting that money often has little impact on electoral and legislative outcomes. Although in 2002 candidates who raised the most money won $90 \%$ of the congressional primary races and $94 \%$ of the general election contests, ${ }^{40}$ antireformers emphasize that contributors often give to candidates who are popular among noncontributors and likely to win. ${ }^{41}$ According to antireformers, assuming that money influences outcomes paternalistically implies that voters cannot sift through various information to make decisions. ${ }^{42}$

While the antireformers' assertion that donors follow voters may accurately describe some political gifts, the extent to which electoral and legislative outcomes remain unaffected by money is a contested empirical question that one cannot answer with mathematical precision. For example, how does one establish that most candidates win elections because of variables unrelated to money? In addition to money, relevant variables might include the ideological predisposition

39 See Helen Dewar, For Campaign Reform, a Historically Uphill Fight, WASH. PosT, Oct. 7, 1997, at A5 ("If history is any guide, Mark Hanna, the legendary turn-of-thecentury Republican boss, got it right when it came to the enduring power of money in American politics. 'There are two things that are important in politics,' Hanna said in 1895. 'The first is money and I can't remember what the second one is."').

${ }^{40}$ LIOZ \& CASSADY, supra note 8, at 14.

${ }^{41}$ See Smith, supra note 1, at 1065 (noting that the correlation between winning elections and spending money is the result of donors giving to candidates likely to win, not the result of donors' money buying elections); Kathleen M. Sullivan, Political Money and Freedom of Speech, 30 U.C. DAVIS L. REV. 663, 677 (1997) (“[A] candidate's ability to attract funds is at least to some extent an indicator of popularity. Money may flow directly in response to the candidate's ideas or indirectly in response to the candidate's popularity with others as reflected in poll numbers and the like." (footnote omitted)). The Court has also made similar assumptions. Mass. Citizens for Life, 479 U.S. at 258 ("Relative availability of funds is after all a rough barometer of public support.").

${ }^{42}$ See Jill E. Fisch, Frankenstein's Monster Hits the Campaign Trail: An Approach to Regulation of Corporate Political Expenditures, 32 WM. \& MARY L. REV. 587, $621-22$ (1991) (" $[\mathrm{T}]$ he paternalistic notion that corporate spending should be regulated because otherwise large corporate spenders would be able to 'buy' the political system is unpersuasive.... [T] he tombs of television are filled with the remains of expensive advertising campaigns that failed." (footnotes omitted)). Reformer Dan Ortiz has also acknowledged this phenomenon. See Daniel R. Ortiz, The Democratic Paradox of Campaign Finance Reform, 50 STAN. L. REV. 893, 895 (1998) (“[T] he equality-protecting and other rationales underpinning most forms of campaign finance regulation are premised on doubts about voters' civic capabilities. This is the democratic paradox of campaign finance reform.”). 
of a candidate's electorate; the most pressing issues on election day; a candidate's ideology, personality, and credibility; a candidate's campaign strategy and execution of that strategy; the amount and type of free media a candidate receives; and a host of other factors that evade quantification. Similar indeterminate factors prevent measuring the extent to which money does or does not influence legislative deliberations. $^{43}$ No static, controlled set of variables exists that allows the isolation and mathematical determination of the electoral or legislative influence of one causal factor, such as financial contributions.

Although the precise impact of money is unascertainable, the $\mathrm{Su}-$ preme Court in McConnell upheld restrictions based on an extensive evidentiary record that candidates, parties, and others believe that money influences electoral outcomes and thus devote extensive time and energy toward raising it. ${ }^{44}$ The Court observed that parties "kept tallies of the amounts of soft money raised by each officeholder, and 'the amount of money a Member of Congress raise[d] for the national political committees often affect[ed] the amount the committees g[a]ve to assist the Member's campaign." 45 Parties crafted "menus of opportunities for access to would-be soft-money donors, with increased prices reflecting an increased level of access." ${ }^{, 6}$ Lobbyists, CEOs, and wealthy individuals donated substantial sums to parties "for the express purpose of securing influence over federal officials." ${ }^{47}$

Other factors suggest money leads to political success. Litigants have sought to invalidate campaign regulation-and courts have sometimes complied-on the theory that money plays a critical role in the political process. For example, the Court in Buckley v. Valeo decided to invalidate spending limits because "virtually every means of communicating ideas in today's mass society requires the expenditure

${ }^{43}$ An examination of the influence of money on legislative deliberations, for example, might include an analysis of the merits of each bill introduced in a legislative session, alternative proposals, and the influence of monetary factors relative to nonmonetary factors in the passage of each bill.

${ }^{44}$ Cf. E. Joshua Rosenkranz, Faulty Assumptions in "Faulty Assumptions": A Response to Professor Smith's Critiques of Campaign Finance Reform, 30 CONN. L. REv. 867, 886 (1998) ("Professor Smith's conception is contradicted by that of a veritable army of politicians, consultants, and operatives, each of whom behaves as if we were living in a world where campaign spending can win elections.... [C] hanges in candidates' favorability ratings undeniably track advertising expenditures, not fundraising numbers.").

${ }^{45}$ McConnell v. FEC, 124 S. Ct. 619, 662 (2003) (alteration in original) (quoting McConnell v. FEC, 251 F. Supp. 2d 176, $474-75$ (D.D.C. 2003)).

${ }^{46} I d$. at 665 .

${ }^{4} I d$. at 662 . 
of money." 48 The Court in Nixon v. Shrink Missouri Government PAC instructed that contribution limits not be so low as to "drive the sound of a candidate's voice below the level of notice ...." If contributions were merely a straw poll that reflected popularity, many successful candidates would probably not spend several hours a day fundraising. ${ }^{50}$

While voters make decisions in the voting booth, money often plays a critical role in the agenda-setting and persuasion that precede election day. ${ }^{51}$ Granted, some voters ignore television advertisements and other tools of political deliberation that campaign money finances. But to assume such vehicles have no impact on voter contemplation denies the importance of the deliberative process. ${ }^{52}$

Finally, even when contributors give to popular candidates who are likely to win, money remains important. While these contributors

48424 U.S. 1,19 (1976).

49528 U.S. 377, 397 (2000).

${ }^{50}$ See Richard L. Berke, A Senate Candidate's Refrain: ‘Could You Stretch It to \$500?, N.Y. Times, June 8, 2002, at A1 (quoting Democratic Senatorial Campaign Committee Executive Director James Jordan, who stated that good candidates "show a lot of discipline and spend six to eight hours a day in their call room raising money ...."); see also Peter Lindstrom, Ctr. FOR Responsive Politics, Congressional Operations: CONGRESS SPEAKS-A SuRveY OF THE 100TH CONGRESS 92 (1988) (indicating that $29.7 \%$ of members of Congress and $47.5 \%$ of congressional staffers responding to survey revealed that the demands of campaign fundraising significantly infringed on the time devoted to legislative work); Vincent Blasi, Free Speech and the Widening Gyre of Fund-Raising: Why Campaign Spending Limits May Not Violate the First Amendment After All, 94 COLUM. L. REV. 1281, 1282 (1994) (observing that candidates spend increasing amounts of time in activities related to fundraising, and that "[a] major goal of campaign finance reform is coming to be-and surely ought to be-to protect the time of elected representatives and candidates for office").

${ }^{51}$ See RonAld DWORKIN, SOVEREIGN VIRTUE 198 (2000) (distinguishing between equality of deliberation, or "influence," and decision making, and arguing that "equality of influence is incompatible, even in principle, with other attractive aspects of an egalitarian society"); Foley, supra note 14, at 1226 (observing that voting is preceded by the agenda-formation stage "in which matters to be voted upon are identified" and "the 'argumentative stage,' in which competing factions of the electorate attempt to persuade the mass of undecided voters to agree with their positions"); Andrei Marmor, Authority, Equality and Democracy 18 (Jan. 2003) (unpublished manuscript, available at http://lawweb.usc.edu/cleo/working-papers/olin/documents/03_15_paper.pdf) (asserting that "a principle of equality need not be the same kind of equality with respect to these two main stages of the political process, namely, deliberation and decision").

${ }^{52}$ Cf. Jim Rutenberg, Campaign Ads Are Under Fire for Inaccuracy, N.Y. Times, May 25, 2004, at A21 (“'Even people who don't think there is much information in these ads and say they don't learn anything from them tell us they believe factoids they could only have gotten from these ads, and they're wrong...." (quoting Brooks Jackson, director of Factcheck.org, an Annenberg Public Policy Center website)). 
might not enjoy greater influence over the outcome of the election, they often give their contributions with the hope of purchasing special access and influence during legislative deliberation.

\section{The Limits of Virtual Representation by the Wealthy}

Antireformers also downplay disparities in wealth by arguing that current contribution patterns do not harm the less wealthy. Many wealthy individuals underwrite candidates, causes, and political efforts that help the less fortunate. ${ }^{53}$ For example, to a large extent a handful of wealthy patrons bankrolled Theodore Roosevelt's 1912 Bull Moose campaign and Senator Eugene McCarthy's 1968 antiwar campaign. ${ }^{54}$ Wealthy donors fund voter registration projects, get-out-the-vote drives, and other grassroots efforts in poorer communities. ${ }^{55}$ Along similar lines, the antireformers argue, the donor class is ideologically diverse. Money from wealthy liberals cancels out the money from wealthy conservatives, and the distributional disparities have little effect on the content of political debate. ${ }^{56}$ The tens of millions of dol-

${ }^{53}$ See Smith, supra note 1, at 1082 ("Historically, candidates with large constituencies among the poor and the working class have obtained their campaign funds from a small base of wealthy donors.").

${ }^{54}$ See id. at 1073 (noting that "well-known public figures challenging the status quo have traditionally relied on a small number of wealthy patrons to fund their campaigns" and citing Roosevelt's and McCarthy's campaigns as examples).

55 As Bradley Smith notes:

$[\mathrm{I}] \mathrm{t}$ is hard to imagine that any but the most extreme advocates of campaign

finance reform really want to reduce the flow of funds for get-out-the-vote and voter registration drives, or even for yard signs, buttons, bumper stickers and slate cards-the items for which soft money is specifically authorized by statute.

Bradley A. Smith, Soft Money, Hard Realities: The Constitutional Prohibition on a Soft Money Ban, 24 J. LEGIS. 179, 182 (1998).

${ }^{56}$ See, e.g., Lillian R. BeVier, The Issue of Issue Advocacy: An Economic, Political, and Constitutional Analysis, 85 VA. L. REV. 1761, 1780 (1999) (acknowledging the possibility that disparities in wealth have "very little 'distorting effect" because "wealthy individuals (and groups) 'cancel each other out," and citing DEBORAH BECK ET AL., ANNENBERg PUb. POL'Y CTR., IsSUE AdVOCACY AdVERTISING DURING THE 1996 CAMPAign 3 (1997), showing that "ads generally supportive of Democratic positions and those generally aligned with Republican positions were evenly split”). Bradley Smith has also noted that

corporate PACs, which presumably would be considered a voice of the 'rich,' routinely give forty to sixty percent of their contributions to Democratic Party candidates, despite the general belief that the Republican Party favors those with high incomes. That the 'wealthy' should be less homogenous than other political elites is no shock.

Bradley A. Smith, Money Talks: Speech, Corruption, Equality, and Campaign Finance, 86 GEO. L.J. 45, 94 (1997). 
lars given by liberal billionaire George Soros to 527s-groups covered by section 527 of the Internal Revenue Code-that run anti-Bush attack ads, the argument goes, offset the tens of thousands of $\$ 2000$ contributions raised by Republican President George W. Bush. ${ }^{57}$

Outside of a few anecdotes, however, the antireformers provide no persuasive evidence that the ideological spending and contributions of the donor class mirror the political disposition of the public as a whole. Indeed, data suggests wealthier contributors are unrepresentative of the greater public. ${ }^{58}$ Antireformers also provide little empirical data that wealthier Republicans always perfectly represent the interests of poorer Republicans or that richer Democrats adequately represent more impoverished Democrats.

Even if the donor class accurately reflected the political spectrum of people of all financial backgrounds, such "virtual" representation of non-contributors sacrifices an important value-individual autonomy.

${ }^{57}$ In the aftermath of the ban on unlimited soft money contributions to political parties, a few individuals contributed millions to groups organized under section 527 of the Internal Revenue Code. These groups spend such money to support or attack particular candidates, and some reformers have worked to restrict contributions to such groups. See Dan Balz \& Thomas B. Edsall, Democrats Forming Parallel Campaign: Interest Groups Draw GOP Fire, WASH. POST, Mar. 10, 2004, at A1 ("The Democratic 527 organizations have drawn support from some wealthy liberals determined to defeat Bush. They include financier George Soros and his wife, Susan Weber, who gave \$5 million to ACT and $\$ 1.46$ million to MoveOn.org ...."); see also Donald B. Tobin, Anonymous Speech and Section 527 of the Internal Revenue Code, 37 GA. L. REV. 611, 620-36 (2003) (providing a history of section 527 and an explanation of how section 527 organizations operate).

${ }^{58}$ See Oren Levin-Waldman, The Minimum Wage and The Cause of Democracy, 61 REV. SOC. ECON. 487, 501 (2003) ("As household income rises, individuals are more likely to vote and their votes are more likely to be in favor of policies less favorable to the disadvantaged."), available at 2003 WL 57281735; Louise Witt, Whose Side is God On?, AM. DemogRAPHICS, Feb. 2004, at 18, 19 (2004) ("Respondents with less education and lower household incomes are more likely to say that religion should 'very much' play a role in public policy."); Michael Kranish \& Glen Johnson, Full Scope of Decision Uncertain, BOSTON GLOBE, May 3, 2003, at A1 (indicating that although the country is split fairly evenly between registered Democratic voters and Republican voters, in the 2002 election cycle the Democratic National Committee received just $\$ 67$ million in hard money contributions compared to the Republican National Committee's \$164 million); Wilcox July 3, 2004 Chart, supra note 10 (indicating that $63 \%$ of $\$ 1000$ contributors to presidential candidates during 2000 primaries identify themselves as conservative, $13 \%$ consider themselves moderate, and $24 \%$ consider themselves liberal).

In addition to providing no evidence connecting wealthy contributor ideology to that of society as a whole, the antireformers provide no theory as to why this alleged balance will exist forever into the future. Further, the antireformers fail to explain why wealthy contributors sympathetic to the poor will consistently, with regard to each candidate and each issue, choose ideology over self-interest. 
Individual autonomy involves choice-the "right [of individuals] to make important decisions defining their own lives for themselves." ${ }^{59}$ Autonomy means "having a say in what affects you," including how one is governed. ${ }^{60}$ This choice is an integral part of self-affirmation. While an individual's freedom from government interference is perhaps the most familiar concept of individual autonomy, ${ }^{61}$ the scope of a person's choice does not depend merely upon government action or inaction. Other variables-access to resources, the actions of other non-governmental actors-are relevant as well. Furthermore, autonomy requires the existence of meaningful alternatives from which to choose. $^{62}$

By discounting the importance of meaningful participation in determining the viability of candidates, the antireformers compromise critical autonomy values. An individual who cannot give large sums reaps fewer benefits of self-affirmation and is less able to exercise control over her life and community.

In contrast, the wealthier contributor often uses one toolmoney-to implement his agenda by mobilizing another tool-noncontributing voters likely to cast a ballot for the contributor's candidate. This is not to suggest that the wealthy should not spend money on voter mobilization or that voters predisposed to vote for particular candidates do not exercise choice in deciding whether to vote or stay home. But serving as a target of get-out-the-vote funds is no substitute for the autonomy enjoyed by wealthier contributors. Simply controlling less wealth does not make one unworthy of the self-determination

${ }^{59}$ RONALD Dworkin, LiFE's DOMINION 222 (1993); see CASS R. SUnSTEIn, DEMOCRACY AND the Problem of Free Speech 138 (First Free Press Paperback ed. 1995) (noting that autonomy can be defined as permitting or empowering individuals to be "authors of the narratives of their own lives").

${ }^{60}$ Erwin Chemerinsky, The Supreme Court, 1988 Term-Foreword: The Vanishing Constitution, 103 HARV. L. REV. 43, 75 (1989) (defining individual autonomy as "the importance of each individual having a say in how he or she is governed"); see also Michael $\mathrm{H}$. Shapiro, Introduction: Judicial Selection and the Design of Clumsy Institutions, 61 S. CAL. L. REV. 1555, 1567 n.48 (1988) (“'Autonomy,' as used in the text, refers to that aspect of autonomy dealing with opportunities to pursue preferences-an ability generally enhanced by having a say in what affects you.").

${ }^{61}$ See Isaiah Berlin, Two Concepts of Liberty, in FOUR ESSAYS ON LIBERTY 118, 122-31 (1969) ("I am normally said to be free to the degree to which no man or body of men interferes with my activity. Political liberty in this sense is simply the area within which a man can act unobstructed by others.").

${ }^{62}$ See JOSEPH RAZ, THE MORALITY OF FrEedOM 373-77 (1986) ("All that has to be accepted is that to be autonomous a person must not only be given a choice but he must be given an adequate range of choices.”). 
that accompanies political participation through large financial contributions.

In short, the antireformers fail to explain why the lack of wealth is of lesser consequence to autonomy than other factors that limit an individual's ability to support a candidate, such as contribution and spending restrictions.

\section{B. Democratic Structure Versus Economic Markets}

Antireformers argue that even if money does influence political outcomes, campaign contributions allow people to convert their hard work and talents from the economic sphere into attributes in the political sphere. ${ }^{63}$ Disparities in wealth are no less fair than inequalities in other political tools, such as education, celebrity, time to volunteer, speaking ability, personal magnetism, intelligence, or good looks. ${ }^{64}$ Unlike these other attributes, money is available to a broad cross section of the public and to different individuals at different times due to the fluidity of the American economy.

The antireformers overstate the fairness and fluidity of market distribution and fail to acknowledge the distinct values, objectives, and structure of democracy.

\section{The Limits of Economic Mobility}

Professor Bradley Smith claims that in "America's private markets wealth and property allocations are constantly changing," and that "[m] ost Americans move up and down the income and wealth scale

${ }^{63}$ See Smith, supra note 1, at 1080 ("The question is whether people will be allowed to convert their varied talents into political influence.").

${ }^{64}$ See BeVier, supra note 1, at 1118 ("Eliminate the unequal influence of wealth and every other source of unequal political influence will remain-intelligence, personal magnetism, celebrity status, organizational skills, communication skills, and so on."); Smith, supra note 56, at 89 ("The question, however, becomes why this single source of unequal political influence should be removed from the process.... Why should access to money be singled out? What are the characteristics that allegedly make money a particular vice in our political system?" (footnote omitted)). Kathleen Sullivan has noted that

legislators respond disproportionately to the interests of some constituents all the time, depending, for example, on the degree of their organization, the intensity of their interest in particular issues, and their capacity to mobilize votes to punish the legislator who does not act in their interests.... It is at least open to question why attempts to achieve the same ends through amassing campaign money are more suspect, at least in the absence of personal inurement.

Sullivan, supra note 41 , at 680 . 
over time-many with stunning rapidity." ${ }^{\prime 65}$ Professor Lillian BeVier, arguing that the American economy and political power are dynamic, cites data showing that among taxpayers in the lowest bracket in 1979, only $14.2 \%$ were still there nine years later, and $14.7 \%$ had risen all the way to the highest bracket. ${ }^{66}$ She writes that " $\left.\mathrm{t}\right]$ he familiar saying 'three generations from shirtsleeves to shirtsleeves' is but a homely way of capturing the universal flux." ${ }^{67}$ Thus, BeVier asserts, "even though 'wealth' at any particular point in time may be correlated with political power at that point in time, both wealth and power will be constantly in flux."

Professor BeVier's taxpayer data provides an incomplete picture of economic mobility in the United States. The source BeVier cited acknowledged that the data's seemingly high economic mobility stemmed from heavy representation of young adults in the study's bottom quintile in 1979. As one might expect, this group's earnings rose as they aged and gained skills. ${ }^{69}$ Further, every taxpayer in the study's pool filed tax returns for nine consecutive years. Thus, the study does not accurately reflect the mobility of poorer Americans, who often do not earn enough to file tax returns. ${ }^{70}$

Professor BeVier's intragenerational taxpayer study also fails to capture the impact of children's class origins on economic mobility later in life. ${ }^{71}$ Whereas a son born into the top decile of income has a

65 Smith, supra note 56 , at 68 .

${ }^{66}$ See BeVier, supra note 56, at 1778-79 (quoting David R. Henderson, The Richand Poor-Are Getting Richer, RED HERRING, Aug. 1997, at 120, 120, reprinted in HoOvER DiG., 1998 No. 1, at 17, 18-19 ("[O]f the taxpayers in the bottom quintile in 1979, only 14.2 percent (or one in seven) were still there in 1988. Meanwhile, 20.7 percent had moved to the next higher fifth, 25 percent to the middle fifth, 25.3 percent to the second-highest fifth, and 14.7 percent to the highest fifth.")).

${ }^{67}$ Lillian R. BeVier, Campaign Finance Reform: Specious Arguments, Intractable Dilemmas, 94 COLUM. L. REV. 1258, 1264 (1994).

68 BeVier, supra note 56, at 1779 .

69 See Henderson, supra note 66, at 18-19 ("The most important factor [in mobility] is age. Heavily represented in the bottom quintile are young people, who have just graduated from high school or college and are living on their own. Their current earnings are low, but as they age and gain skills, their earnings rise.”).

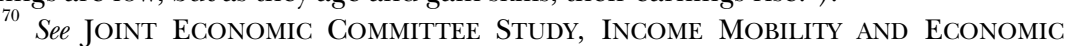
OPPORTUNITY (June 1992) (acknowledging that the study does not provide a complete picture of income mobility of poorer Americans who sometimes do not earn enough to file tax returns), available at http://www.house.gov/jec/middle/mobility/mobility. htm (last visited Sept. 20, 2004). The study was based upon 14,351 taxpayers who filed tax returns in every year from 1979 through 1988. Id.

71 See DANiEl HaYs LowENSTEIN \& Richard L. HASEN, ElECTION LAW: CASES AND MATERIALS 743-44 (2d ed. 2001) ("BeVier provides no empirical support for her claim about redistribution of wealth across generations, and it turns out that long-term longi- 
$40.7 \%$ chance of attaining the top quintile as an adult, a son from the poorest decile has only a $3.7 \%$ chance of making it to the top quintile. $^{72}$ A 2002 study suggests that the United States leads only two of the seven advanced nations examined-South Africa and England-in intergenerational earnings mobility. ${ }^{73}$ Economic and sociological studies of American intergenerational mobility confirm that "children of disadvantaged class origins have to display far more merit than do children of more advantaged origins in order to attain similar class positions." ${ }^{, 74}$

Professor BeVier's focus on the income of taxpayers also overlooks the important role of wealth in measuring class mobility. Wealth considers access to resources in the context of financial obligations such as debt. ${ }^{75}$ Wealth may be even more relevant to one's ability to give large financial contributions than income is. As two scholars noted in highlighting the significance of wealth:

tudinal empirical studies (studying the same people or families over time) may not exist. In the shorter term, the empirical picture does not support BeVier.”).

${ }^{72}$ Samuel Bowles \& Herbert Gintis, The Inheritance of Inequality, J. ECON. PERSP., Summer 2002, at 3, 5. Economic studies going back to the mid-1960s found a low correlation between parents' and sons' incomes. See generally PETER M. BLAU \& OTIS Dudley DunCAN, THE AMERICAN OCCUPATIONAL STRUCTURe 26-38 (1967) (showing intragenerational mobility rates based on a father's occupation). But the veracity of those results has not held over time. Recent research has revealed that early conclusions showing little correlation between generational earning patterns were based on faulty measurements. First, individuals' mistakes in recalling the income of their parents led to inaccurate information. Second, the early studies' reliance on singleyear or even three-year income samples often reflected temporary increases and depressions in income that misrepresented individuals' longer-term income averages. See Bowles \& Gintis, supra, at 4 (discussing "mistakes in reporting income, particularly when individuals were asked to recall the income of their parents, and transitory components in current income uncorrelated with underlying permanent income").

${ }^{73}$ See The Century Foundation, Rags to Riches: The American Dream is Less COMMON IN THE UNITED STATES THAN ElSEWHERE 7 \& fig.4, 8 (2004) (suggesting that citizens of Finland are followed by Swedes, Canadians, Germans, Americans, South Africans, and the British in intergenerational earnings mobility, but noting that the results are inconclusive because of differences in data sources and methods (citing Gary Solon, Cross-Country Differences in Intergenerational Earnings Mobility, J. ECON. PERSP., Summer 2002, at 59, 62 tbl.1)), available at http://www.tcf.org/Publications/ EconomicsInequality/ragrichrc.pdf.

${ }^{74}$ Richard Breen and John H. Goldthorpe, Class Inequality and Meritocracy: A Critique of Saunders and an Alternative Analysis, 50 BRIT. J. SOC. 1, 21 (1999).

${ }^{75}$ See Melvin L. Oliver \& Thomas M. Shapiro, Black Wealth/White WeAlth: A NeW PersPective on RACIAL IneQuality 30 (1997) ("Wealth is the total extent, at a given moment, of an individual's accumulated assets and access to resources, and it refers to the net value of assets . . less debt held at one time."). 
[T] he reality for most families is that income supplies the necessities of life, while wealth represents a kind of "surplus" resource available for improving life chances, providing further opportunities, securing prestige, passing status along to one's family, and influencing the political process. ${ }^{76}$

Economic mobility is even more dismal in terms of wealth. One study of disposable wealth revealed that only $1.4 \%$ of families in the lowest quintile had ascended to the highest quintile fifteen years later. $^{77}$ Most of the change that does occur is insignificant. Of American households in the bottom fifth in net worth in 1984, five years later $90.1 \%$ were still in the bottom two-fifths and only $3.3 \%$ had risen to the top two-fifths. ${ }^{78}$ Of those in the top fifth in net worth in 1984, five years later $92.8 \%$ were in the top two-fifths and only $1.5 \%$ had fallen to the bottom two-fifths. ${ }^{79}$

Further, while differences in hard work and talent among individuals sometimes cause disparities in wealth, ${ }^{80}$ the antireformers give inadequate attention to structural factors such as upbringing, sexism, and racism that also cause disparities. ${ }^{81}$ The government-sponsored racial covenants of a few decades ago, for example, continue to shape

${ }^{76} I d$. at 32 (emphasis added). While studies have not engaged in detailed analyses of whether income or wealth has the greater impact on the likelihood that an individual will make political contributions, some commentators suggest that, in certain situations, wealth has a greater impact on charitable contributions. See, e.g., Martin Feldstein, The Income Tax and Charitable Contributions, Part I-Aggregate and Distributional Effects, 28 NAT'L TAX J. 81, 90 (1975) (“At . . very high income levels, adjusted gross income is a less adequate measure of economic income and wealth is a more important influence on giving.").

77 See Nancy A. Jianakoplos \& Paul L. Menchik, Wealth Mobility, 79 REv. ECON. \& STAT. 18, 20 (referring to the number of households that ascended from the lowest wealth quintile (less than $\$ 5473$ ) to the highest (more than $\$ 99,188$ ) between 1966 and 1981).

78 See Díaz-Giménez et al., supra note 13, at 14 tbl.7 (comparing differences in wealth holdings in 1984 and 1989).

${ }^{79} I d$.

${ }^{80}$ We can also assume, for the sake of argument, that these characteristics do not stem from structural environmental influences beyond the control of the individual. Cf. Rosenkranz, supra note 44, at 894 (“'[P] ersuasive' powers rest on a different plane than monetary power. The power of persuasion, which involves skills 'such as writing [and] speaking,' goes to the heart of what the First Amendment is about in a way that the power of the purse does not." (alteration in original)).

${ }^{81}$ Cf. Kenneth Arrow, What Has Economics to Say About Racial Discrimination?, J. ECON. PERSP., Spring 1998, at 91, 98 ("Models of racial discrimination in which all racial attitudes are expressed through the market will get at only part of the story. At each stage, direct social transactions unmediated by a market play a role. Even the market manifestations will be altered by these direct social influences."). 
housing values, the quality of public education, and other vehicles that allow individuals to acquire wealth. ${ }^{82}$

These structural factors also influence the fluidity of income and wealth among particular racial groups. ${ }^{83}$ In a study of men who turned twenty-one after 1980, 47\% of whites reached middle class earnings by age thirty, whereas only $19 \%$ of blacks had done so. ${ }^{84}$ African Americans are nearly five times more likely than whites to fall from the top income quartile to the bottom quartile, while African Americans born to the bottom quartile attain the top quartile at less than one-half the rate of whites. ${ }^{85}$ In a study of American wealth mobility over 15 years, $0 \%$ of the African American males in the study rose from the lowest wealth decile to the highest. ${ }^{86}$

${ }^{82}$ See Richard Thompson Ford, The Boundaries of Race: Political Geography in Legal Analysis, 107 HARV. L. REV. 1843, 1848 (1994) (describing "the responsibility of federal policy for the persuasiveness of racially restrictive covenants," resulting in "significant disinvestment in black areas by private institutions" (internal quotation marks and footnote omitted)); $c f$. RAYMOND S. FrankLin, SHADOWS OF RACE AND Class 124-25 (1991) (noting that homes owned by middle-class African Americans "do not appreciate as rapidly in value over time as homes owned by whites"); OLIVER \& SHAPIRO, supra note 75 , at 40, 150 (observing that "similar housing investments made by whites and blacks yield vastly divergent returns-to the distinct disadvantage of blacks").

${ }^{83}$ Cf. Spencer Overton, But Some Are More Equal: Race, Exclusion, and Campaign Finance, 80 TEX. L. REV. 987, 1014-15 (2002) ("[S]peech markets created in the campaign finance context are not 'neutral' or 'fair,' but are based on existing property allocations that have been shaped by illegitimate factors such as past discriminatory public policies.").

${ }^{84}$ Mobility in America: Up, Down and Standing Still, The ECONOMIST, Feb. 24, 1996, at 30. According to the Panel Study of Income Dynamics (PSID), entering the middle class is getting harder. A study found that the mean and median family net worth for whites as $\$ 291,800$ and $\$ 95,000$ respectively, but only $\$ 59,100$ and $\$ 7500$ for blacks. Both gaps have grown larger, not smaller, over time. Elena Gouskova \& Frank Stafford, Trends in Household Wealth Dynamics, 1999-2001, at 2, 6-7 tbls.2, 3 (2002), available at http://psidonline.isr.umich.edu/Publications/Papers/TrendsIndynamics19992001. pdf (last visited Sept. 18, 2004).

${ }^{85}$ As one study found:

Downward mobility from the top quartile to the bottom quartile is nearly five times as great for blacks as for whites. Thus, whatever it is that accounts for their success, successful blacks do not transmit it to their children as effectively as do successful whites. Correspondingly, blacks born to the bottom quartile attain the top quartile at one half the rate of whites.

Bowles \& Gintis, supra note 72, at 7; see also Thomas Hertz, Rags, Riches and Race: The Intergenerational Economic Mobility of Black and White Families in the United States (Apr. 9, 2003) ("While only $17 \%$ of whites born to the bottom decile of family income remained there as adults, for blacks the figure was 42\%."), available at http:// academic2.american.edu/ hertz/ (last visited Sept. 16, 2004).

${ }^{86}$ See Jianakoplos \& Menchik, supra note 77, at 18, 20, 28 (measuring American wealth in 1966 and 1981). 
In short, while some economic mobility exists in the United States, markets are not so fair and fluid as to extinguish concerns about the impact of wealth on democratic participation.

\section{The Distinctions Between Money and Other Political Tools}

Despite the antireformers' attempts to characterize money as a democratizing tool that reformers selectively demonize, money differs from characteristics like celebrity, time to volunteer, speaking ability, personal magnetism, and good looks.

These political tools are randomly distributed throughout society in a way that wealth is not. As examined above, wealth is concentrated among certain groups and neighborhoods and remains so for generations, due in part to illegitimate factors like past racial discrimination. $^{88}$ To the extent that democracy should reflect and respond to the needs of society as a whole, individuals within different neighborhoods and ethnic, ideological, political, and economic groups should have access to important tools of political participation.

Further, tools like speaking skills, personal magnetism, and good looks are more personal to individuals and less fungible than money. ${ }^{90}$

${ }^{87}$ Counter to the claims listed by the antireformers, those who are sensitive to class are concerned about disparities in political attributes other than money. For example, education facilitates democratic participation, and the undereducation of several populations poses a democratic problem.

${ }^{88}$ See supra Part II.B.1.

${ }^{89}$ There is also a question as to whether disparities in media ownership should prompt concerns about distribution. See Foley, supra note 14, at 1252 ("The owners of newspapers should have no greater opportunity, simply by virtue of owning this property, than any other citizen to attempt to persuade undecided voters how to vote on election day."); Richard L. Hasen, Campaign Finance Laws and the Rupert Murdoch Problem, 77 TEX. L. REV. 1627, 1665 (1999) ("[I]t seems anomalous to exempt Rupert Murdoch, defense contractors, Mickey Mouse and a host of other characters [from restrictions] simply because they used their wealth to buy a newspaper or broadcast station."); Eugene Volokh, Freedom of Speech and Speech About Political Candidates: The Unintended Consequences of Three Proposals, 24 HARV. J.L. \& PUB. POL'y 47, 58 (2000) (arguing that "under [the money as property] approach, the government would acquire broad power to control newspapers ... and anyone else who hires others to participate in creating a speech product"). Simply because the media context raises questions of distribution, however, does not mean that questions of distribution in the campaign finance context are irrelevant. Indeed, the proposal advanced in Part III, infra, uses technology, tax credits, and matching funds to enhance the importance of smaller contributions not only relative to large contributors, but also relative to owners of media outlets and those who possess political talents such as celebrity, time to volunteer, speaking ability, personal magnetism, and good looks.

${ }^{90}$ Cf. Margaret Jane Radin, Market-Inalienability, 100 HARV. L. REV. 1849, 1885 (1987) ("In our understanding of personhood we are committed to an ideal of indi- 
While money is universally quantifiable, ${ }^{91}$ the other political tools generally defy objective measurement. Perhaps due to the easy quantification of money, legislatures routinely tax, redistribute, and restrict the use of financial resources, but regulation to offset one's speaking skills, magnetism, or good looks represents a greater infringement on personal autonomy. ${ }^{92}$

Money is also unique because of the critical role of the political process in shaping wealth distribution. Politicians do not generally oversee rules regarding the distribution of celebrity, time to volunteer, speaking skills, personal magnetism, and good looks, but they do write the tax code, determine government spending, and regulate commerce. Unlike other political tools, wealth can drive government decisions that will increase or preserve the very political tool used-the wealth-and further entrench the political power of the holder. ${ }^{93}$

Perhaps most important, money differs from other political tools because economic markets represent a primary sphere of power in our society, and legitimate questions exist as to whether political influence should be another commodified fringe benefit of success in the economic sphere. To the extent one values diversity in concentrations of power, the democratic sphere should be as independent as possible from concentrated power in the economic sphere.

\section{The Limits of Wealth Maximization}

While some might dismiss concerns about fairness in the distribution of wealth as irrelevant to the singular goal of wealth maximization, ${ }^{94}$ such an approach is unwarranted in the political sphere due to

vidual uniqueness that does not cohere with the idea that each person's attributes are fungible, that they have a monetary equivalent, and that they can be traded off against those of other people.").

${ }^{91}$ Cf. AleXander Heard, The Costs OF Democracy 90 (1960) (explaining that money "is a universal, transferable unit infinitely more flexible in its uses than the time, or ideas, or talent, or influence, or controlled votes that also constitute contributions to politics").

${ }^{92}$ Cf. Spencer Overton, Mistaken Identity: Unveiling the Property Characteristics of Political Money, 53 VAND. L. REV. 1235, 1262 (2000) ("While the amorphous nature of speech is likely to lead to arbitrary appraisals of speech, government can respond to issues of scarcity and distribution exhibited by political money with some semblance of objectivity due, in part, to the quantifiability of the interest.").

${ }_{93}$ Cf. Foley, supra note 14, at 1204 ("An important function of electoral politics is to determine how wealth should be distributed among society's members. The existing distribution of wealth at the time of any particular election should not affect the electorate's determination of what the distribution should be henceforth.").

${ }^{94}$ See Richard A. POSNER, ECONOMIC ANALYSIS OF LAW 460-61 (4th ed. 1992) (ex- 
the broader objectives of democracy. A central function of democratic power is to defend important values and human needs that "rational" markets sometimes ignore. ${ }^{95}$ Such values include, but are not limited to, inclusion, fairness, and opportunity. ${ }^{96}$

The mathematical precision of an economic model is seductive, perhaps because such an approach avoids the complex balancing and the unpredictable outcomes that often characterize democratic compromises. An economic analysis misses important variables, however. For example, in arguing that market incentives are better limitations on corporate spending than are government restrictions, antireformer Professor Jill Fisch writes:

[A]s a matter of social utility, the economic marketplace operates as a far more efficient limitation on corporate political speech than do campaign finance laws. If a corporation wastes a large amount of money on political speech, it will hinder its ability to compete in the traditional business markets and in the stock market. The cost to the corporation of making political expenditures must be justified in terms of overall economic benefit; that is, expenditures should result in lower prices and higher profits-socially optimal results. ${ }^{97}$

While Professor Fisch's work, as a whole, emphasizes voter choice and discounts corporate spending as a causal factor in political outcomes, ${ }^{98}$ such a utilitarian analysis is limited. Even assuming a corporation makes a political expenditure and profits from the election of a particular candidate-imagine that the candidate is pro-growth and skeptical of most environmental regulations-we do not know that these results are socially optimal. Externalities resulting from relaxed

plaining that redistribution of wealth does not increase the overall wealth of society).

${ }^{95}$ See Fiss, supra note 26, at 7 ("The role of the law is neither to perfect nor to replicate the market, but rather to make those judgments that the adherents of law and economics claim are only 'arbitrary,' i.e., a mere matter of distribution."); $c f$. ROBERT KutTner, Everything FOr SAle: The Virtues AND Limits of MARKets 4 (University of Chicago Press 1999) (1996) ("Even in a capitalist economy, the marketplace is only one of several means by which society makes decisions, determines worth, allocates resources, maintains a social fabric, and conducts human relations."); Radin, supra note 90 , at 1851 (" $[\mathrm{T}]$ he characteristic rhetoric of economic analysis is morally wrong when it is put forward as the sole discourse of human life.").

See Jean Braucher, Defining Unfairness: Empathy and Economic Analysis at the Federal Trade Commission, 68 B.U. L. REV. 349, 351 (1988) ("Usually efficiency and fairness, in the sense of (rough) equality in the distribution of resources, are considered competing values which require a tradeoff to reconcile capitalism and democracy." (citing Arthur M. Okun, EQUality ANd EfFiciency: The Big Tradeoff 1-5 (1975))).

${ }^{97}$ Fisch, supra note 42, at 621.

${ }^{98}$ See supra Part II.A.1 for a response to the claim that money is relatively unimportant in politics. 
environmental regulations might cause greater harm to residential neighbors than the value of the benefit to the corporation. Disparities in wealth might have left the residents unable to afford their own advertisement urging voters to support a candidate who favors environmental regulation. Even assuming that the corporation's enhanced productivity outweighs the harm to the neighbors, this says nothing about whether the neighbors are better equipped to bear the costs of looser regulation, or about the fairness of the neighbors bearing the cost. More important, democracy should allow for consideration of certain issues that may transcend markets, such as concerns about preventing increases in cancer rates or miscarriages among residents in the neighborhood.

Further, because many individuals do not work to maximize personal wealth to the exclusion of all other values, factors other than economic gain inspire talented people to work hard. A law school valedictorian's sense of commitment to a broader community, for example, might lead her to accept a position at a low-paying public interest organization. The antireformers fail to explain why people whose talents and hard work are not rewarded by economic markets should have less access to influence in the political sphere.

Although many wealthy individuals make significant contributions to society, the antireformers do not adequately articulate the rationale for extending special benefits in the democratic context to those with financial resources. Lillian BeVier notes that "since the wealthiest taxpayers-those in the top $10 \%$ of income brackets-pay $59.1 \%$ of all federal income taxes," they have an understandable interest in a political process that will determine "how their taxed dollars will be spent.. ${ }^{99}$ This observation, however, does not explain why other Americans who have a great deal at stake, such as a single mother whose children attend public school or a soldier deployed to fight in Iraq, should enjoy less opportunity to participate in political deliberation.

\section{The Unique Role of Widespread Participation in Democracy}

The antireformers also minimize the critical role of meaningful, widespread participation in establishing democratic legitimacy. Some commentators might argue that an allocation of wealth in which the wealthiest $20 \%$ control $80 \%$ of the resources is the price to be paid

${ }^{99}$ BeVier, supra note 56, at 1780. 
for well-functioning economic markets that provide adequate incentives for hard work and innovation. But with regard to democratic exchange and governance, the need for commitment from a diverse, broad base of perspectives suggests that dominance by a homogeneous donor class representing less than $2 \%$ of the voting-age population is problematic.

Scholars have defined citizen participation as "purposeful activities in which citizens take part in relation to government." ${ }^{100}$ Participation is a crucial democratic value. As Justice Brandeis remarked, "the greatest menace to freedom is an inert people." ${ }^{101}$ Participation includes but is not limited to voting; ${ }^{102}$ involvement with or financial support of a campaign, political party, issue, or interest group; and public advocacy and protest. ${ }^{103}$

Widespread participation serves four primary functions. First, it exposes decision makers to a variety of ideas and viewpoints, which ensures fully informed decisions. ${ }^{104}$ Second, it enhances the legitimacy of government decisions, which increases the likelihood that citizens will voluntarily comply with such decisions. ${ }^{105}$ Third, wide-

${ }^{100}$ Stuart Langton, What is Citizen Participation?, in Citizen PARTICIPATION IN AMERICA 13, 17 (Stuart Langton ed., 1978) (emphasis omitted). For a general discussion of the role of citizen participation in a democracy, see PARTICIPATION IN POLITICS: Nomos XVI (J. Roland Pennock \& John W. Chapman eds., 1975); CAROle Pateman, Participation And Democratic Theory (1970); The Case for Participatory Democracy: Some Prospects for a Radical Society (C. George Benello \& Dimitrios Roussopoulos eds., 1971).

${ }^{101}$ Whitney v. California, 274 U.S. 357, 375 (1927) (Brandeis, J., concurring).

102 See Cass R. Sunstein, Interest Groups in American Public Law, 38 StAN. L. ReV. 29, 31 (1985) (asserting that the early Republican conception of political participation included deliberative dialogue and debate, and was not limited to the act of voting). But see John H. Aldrich, Rational Choice and Turnout, 37 AM. J. POL. SCI. 246, 246 (1993) ("Turning out to vote is the most common and important act of political participation in any democracy.").

${ }^{103}$ See James Burkhart et al., Strategies for Political Participation 57-100 (1972) (providing examples of participation); MARY GRISEZ KWEIT \& ROBERT W. KWEIT, IMPLEMENTING CitIZEN PARTICIPATION IN A BUREAUCRATIC SOCIETY: A CONTINGENCY APPROACH 54-56 (1981) (same); Langton, supra note 100, at 21 (same).

${ }^{104}$ See Walter A. Rosenbaum, Public Involvement as Reform and Ritual: The Development of Federal Participation Programs, in Citizen Participation in America 81, 86 (Stuart Langton ed., 1978) (noting that commentators have asserted that "the public interest is most likely to emerge from the interplay and conflict between a multitude of interests"); Nancy Perkins Spyke, Public Participation in Environmental Decisionmaking at the New Millennium: Structuring New Spheres of Public Influence, 26 B.C. ENVTL. AFF. L. REV. 263, 267 (1999) ("Widespread participation exposes decisionmakers to a healthy mix of perspectives, which is believed to improve the decisionmaking process." (footnotes omitted)).

${ }^{105}$ Cf. KWEIT \& KWEIT, supra note 103, at 129 (noting that citizen participation is 
spread participation allows government resources to be redistributed and priorities altered to reflect evolving problems and needs. ${ }^{106}$ Fourth, participation furthers the self-fulfillment and self-definition of individual citizens who play a role in shaping the decisions that affect their lives. ${ }^{107}$

When less than $2 \%$ of voting-age Americans dominate a crucial element of political participation like funding campaigns, a narrow set of ideas and viewpoints obstruct fully-informed decision making. This is especially true in light of the special access many donors enjoy at fundraising events and the homogeneity of the donor class: $70.2 \%$ are male, $70.6 \%$ are age 50 or older, $84.3 \%$ have a college degree, $85.7 \%$ have family incomes of $\$ 100,000$ or more, ${ }^{108}$ and $95.8 \%$ are white. ${ }^{109}$

expected to increase positive attitudes among participants and discussing conflicting empirical evidence on the subject); $c f$. Luis Fuentes-Rohwer, The Emptiness of Majority Rule, 1 MiCH. J. RACE \& L. 195, 201 (1996) ("To deserve the democratic denomination, the people must take part in political affairs.").

${ }^{106}$ See KWEIT \& KWEIT, supra note 103, at 162 (asserting that the goals of public participation include the redistribution of power).

${ }^{107}$ See Frank I. Michelman, Conceptions of Democracy in American Constitutional Argument: Voting Rights, 41 FLA. L. REV. 443, 451 (1989) (discussing a "constitutive" vision of politics whereby citizens define themselves through their participation); see also C.B. MACPHERSON, THE LIFE AND TIMES OF LIBERAL DEMOCRACY 47-48, 51-52 (1977) (asserting that public participation increases "the amount of personal self-development of all the members of the society").

${ }^{108}$ See Wilcox July 3, 2004 Chart, supra note 10 (indicating that of those who made contributions over $\$ 200$ to presidential primary candidates in the 2000 election cycle, $29.8 \%$ were female, $29.4 \%$ were younger than age fifty, $15.7 \%$ had not acquired a college degree, and $14.3 \%$ had family incomes under $\$ 100,000)$. These numbers differ from the U.S. population as a whole in 2000: $50.9 \%$ were female, $72.7 \%$ were younger than age $50,75.6 \%$ of individuals age twenty-five and older had not acquired a college degree, and $86.6 \%$ of the U.S. population had family incomes under $\$ 100,000$. These data are taken from the U.S. Census Bureau. See Denise I. SMith \& REneE E. SPRAGGINS, U.S. BUREAU OF THE CENSUS, GENDER: 2000, at 1 (Sept. 2001) (showing gender data), available at http://www.census.gov/prod/2001pubs/c2kbr01-9.pdf; Julie MeYer, U.S. BuREAU OF THE Census, AGE: 2000, at 4 (Oct. 2001) (showing age data), available at http://www.census.gov/prod/2001pubs/c2kbr01-12.pdf; KURT J. BAUMAN \& NikKi L. GRAF, U.S. BUREAU OF THE CENSUS, EDUCATIONAL ATTAINMENT: 2000, at 3 (Aug. 2001) (showing educational attainment data), available at http://www.census.gov/prod/2003pubs/c2kbr-24.pdf; CARMEN DE NAVAS-WALT ET AL., U.S. BuREAU OF THE CENSUS, MONEY INCOME IN THE UNITED STATES: 2000, at 17 (Sept. 2001) (showing income data), available at http://www.census.gov/prod/ 2001pubs/p60-213.pdf.

${ }^{109}$ See E-mail from Clyde Wilcox, Professor of Government, Georgetown University, to Spencer Overton, Associate Professor of Law, The George Washington University Law School (June 10, 2004, 11:07:40 EST) (on file with author) (indicating that of donors who contributed more than $\$ 200$ who replied to a racial identity question, 95.8\% identified themselves as white, $1.5 \%$ Hispanic, $1.5 \%$ African American, and $0.7 \%$ Asian; about $0.5 \%$ identified themselves as "other"). By comparison, in the 2000 
To the extent that vast disparities exist in the instrumentalities of participation, citizens feel less able to shape the decisions that affect their lives and question the legitimacy of the laws. ${ }^{110}$ Granted, some who cannot contribute, tamed by unbounded economic market rhetoric, may submit to the implication that they lack entitlement to a primary avenue of political participation enjoyed by large contributors. ${ }^{111}$ For others, however, such exclusion may tap into a reservoir of suspicion that they do not count as full citizens within the political community and thus possess inadequate control over their own lives. The indifference of antireformers who either rationalize or idly tolerate such exclusion only compounds the anger, resentment, and frustration felt by those who are excluded.

Although any process of government distribution is inherently subjective and contestable, the lack of widespread participation in campaign financing raises questions about the existing allocation of restrictions, burdens, and benefits. Some of the Founders and classical formalists extended special protections to private property to prevent the unpropertied majority from redistributing wealth through

census $69.1 \%$ of the U.S. population identified themselves as non-Hispanic white, 12.5\% Hispanic, $12.1 \%$ African American, and 3.6\% Asian American. See Elizabeth M. Grieco \& Rachel C. Cassidy, U.S. Bureau of the Census, Overview of Race AND HiSPANIC ORIGIN: 2000, at 10 (Mar. 2001) (showing race and Hispanic origin data), available at http:/ /www.census.gov/prod/2001pubs/c2kbr01-1.pdf; see also JOHN A. Clark \& John M. Bruce, CAmpaign Contributions in Georgia 7 (1994) ("In the 1990 Census, the population of Georgia was reported to be $71 \%$ white and $27 \%$ black. Our pool of respondents was just over $97 \%$ white, with only about $2 \%$ black."); Democracy N.C., The Color OF Presidential Money: N.C. Case Study 1 (2003) (indicating that of North Carolina donors to Republican and Democratic presidential candidates in 2003, 96\% were white), available at http://www.democracy-nc.org/ whatsnew/colormoneyprescharts082003.pdf; Francia, supra note 12, at 30-31 (revealing that of randomly selected contributors who donated at least $\$ 200$ to 1996 congressional campaigns, $99 \%$ were white)

${ }^{110}$ Cf. James A. Gardner, One Person, One Vote and the Possibility of Political Community, 80 N.C. L. REV. 1237, 1247 (2002) ("Generally, participation is most meaningful when ... citizens can play a significant role in shaping the decisions that affect their lives. For this condition to hold, citizens must feel that there is some reasonable prospect for their participation to lead eventually to actions that affect them." (footnote omitted)).

${ }^{111}$ Cf. Jeffrey L. Harrison, Class, Entitlement and Contract, in LAW AND ECONOMICS: New And CRitical Perspectives 221, 229 (Robin Paul Malloy \& Christopher K. Braun eds., 1995) ("Disadvantaged people come to believe that the world is right when they are told how little they have to offer, how little they are entitled to and that they are ultimately to blame.”). 
the political sphere. ${ }^{112}$ Although courts now give greater deference to democratic judgments regarding property, the call to ignore wealth disparities-in the campaign finance context and in political discourse generally-may have a similar effect of preventing democratic institutions from prioritizing and responding to evolving problems and the needs of society as a whole. ${ }^{113}$

In summary, the antireformers' lack of concern about disparities in wealth stems, in part, from an unwavering acceptance of economic market norms, even though such norms often conflict with democratic values and objectives.

\section{Broadening Political Participation Beyond the Donor Class}

The Supreme Court's deference to legislative judgments in McConnell suggests that the political branches serve a unique constitutional function in crafting democratic structure. In assuming this role, lawmakers should make the impact of class on participation a central concern. As established above, money plays an important role in politics, wealth is concentrated among narrow segments of society, and the democratic process features values and objectives that differ from those in the economic sphere.

This Part articulates a clear goal for campaign reform and proposes initial legislative strategies to reduce the impact of wealth on political participation. Rather than focus on restrictions on contributions and spending, ${ }^{14}$ this Part analyzes how matching funds and tax credits for smaller contributions might broaden participation and enhance smaller donors' influence.

112 See NEDELSKY, supra note 17, at 27-28 (explaining that Madison "thought the protection of property should be a central concern for [a] republican government" to maintain stability).

${ }^{113}$ Cf. id. at 260 ("Why has the judiciary virtually abandoned property in some forms, but not others? Why give up the overt formal limits with respect to economic regulation and social assistance, and enforce the power and privilege of property against the egalitarian measures of campaign finance laws?"); Frank Michelman, Political Truth and the Rule of Law, 8 TEL Aviv U. STUD. L. 281, 288 (1988) ("[I]s it not, after all, a fair question why realism and relativism should have been such potent destroyers of juristic absolutism shielding the market manifestations of property rights against legislative control, but so impotent as the Buckley manifesto implies when it comes to their manifestations in the political sphere?").

${ }^{114}$ For a discussion of the boundaries of legislative authority over campaign finance, see Overton, supra note 33, at 666 ("[J] udges lack adequate guidance as to the point at which reforms go too far in infringing on speech.... This Article represents the first step toward developing a framework that will facilitate more principled judicial review of reforms."). 


\section{A. The Problem and the Goal of Reform}

Any goal of campaign reform is shaped by one's understanding of the problem. Reformers have used a handful of slogans to describe their concerns, including complaints that "good candidates cannot afford to run for public office," "big donors corrupt politics," and "too much money is in politics." These conceptions of the problem are vague and incomplete, and the solutions they inspire are often misguided. Equalizing resources among candidates encourages not only good candidates but also bad ones to run for office. Preventing citizens from attempting to influence government officials may stifle democratic activism and entrench incumbents. Reducing the amount of money in politics seems counterproductive, given that Americans spend more on potato chips than on politics. ${ }^{115}$

More pressing are the massive imbalances in access to financial resources that cause disparities in citizen participation in campaigns and in the legislative process. A wealthy donor class gives large contributions that constitute the bulk of funding for American politics and determines which candidates will be viable. In the 2002 election cycle, $0.22 \%$ of the voting-age population gave contributions over $\$ 200$ to federal candidates. ${ }^{116}$ This narrow group contributed $76 \%$ of the funds given to federal candidates by individuals. ${ }^{17}$

Members of the donor class control significant financial resources. While only $13.4 \%$ of American households earned at least $\$ 100,000$ in $2000,{ }^{118}$ one study showed that $85.7 \%$ of contributions over $\$ 200$ and $93.3 \%$ of $\$ 1000$ contributions came from such households. ${ }^{119}$ Less wealthy Americans were better represented among smaller contributors. For example, $73.5 \%$ of contributions of $\$ 100$ or less came from households with incomes of less than $\$ 100,000 .^{120}$

The goal of campaign reform should be to reduce the impact of disparities in wealth on the ability of different groups of citizens to participate in poli-

115 See Smith, supra note 1, at 1059 ("Americans spend more than twice as much money each year on yogurt, and two to three times as much on the purchase of potato chips, as they do on political campaigns." (footnote omitted)).

116 LIOZ \& CASSADY, supra note 8, at 54.

117 See id. at 53 (indicating that in the 2002 congressional elections, $55.5 \%$ of funds given to federal candidates by individuals came from contributors of $\$ 1000$ and $76 \%$ of funds given to federal candidates by individuals came from contributors of $\$ 200$ or more).

${ }^{118}$ DeNavas-WALt ET AL., supra note 11, at 17 tbl.A-1.

${ }^{119}$ See Wilcox July 3, 2004 Chart, supra note 10 (charting demographic data on contributors to presidential candidates during 2000 primaries).

${ }^{120} I d$. 
tics. $^{121}$ Rather than focus on candidate corruption or candidate equalization, campaign reform should empower more citizens to participate in the funding of campaigns. This goal builds on the participatory self-government objective articulated by the Supreme Court in McConnell and calls for reforms that prompt "candidates and political committees to raise funds from a greater number of persons" ${ }^{\text {"122 }}$ and "tangibly benefit public participation in political debate."123

The impact of disparities in wealth might be immediately reduced by reforms that work to create a system in which candidates, political parties, and PACs receive a larger percentage of their funds from a greater number of people in smaller contribution amounts. ${ }^{124}$ Two specific numerical targets might promote clarity, especially when compared to preventing "corruption" and other cloudy goals that current reforms pursue. First, reforms should work to increase the number of people who give money to candidates, parties, or PACs in a

${ }^{121}$ Cf. David A. Strauss, What Is the Goal of Campaign Finance Reform?, 1995 U. CHI. LEGAL F. 141, 141 (observing that one cannot determine whether campaign finance reform is needed, and what reforms might be in order, until one identifies "what the objective of any reform effort should be").

${ }^{122}$ McConnell v. FEC, 124 S. Ct. 619, 656 (2000) (quoting Buckley v. Valeo, 424 U.S. 1, 21-22 (1976) (per curiam)).

${ }^{123} I d$. at 656 . Although the Court in McConnell alluded to a participatory selfgovernment rationale in upholding the ban on soft money, other provisions of BCRA enhanced the political advantages enjoyed by wealthier individuals. For example, the law increased the amount an individual can give to a federal candidate from $\$ 1000$ to $\$ 2000$, and it increased the annual aggregate amount an individual can give to candidates, PACs, and parties from $\$ 25,000$ to $\$ 95,000$. BCRA, Pub. L. No. 107-155, sec. 307, § 315(a) (3), 116 Stat. 81, 102-03 (2002). In the 2003-2004 election cycle, contributions of $\$ 2000$ represented $44 \%$ of the money individuals donated to Republican President George W. Bush and $24 \%$ of such money donated to Democratic presidential nominee John Kerry. See Campaign Fin. Inst., supra note 9, at tbl.3 (indicating sizes of contributions given to presidential candidates).

${ }^{124}$ President Kennedy recognized the importance of broadening participation in the financing of campaigns:

In these days when the public interest demands basic decisions so essential to our security and survival, public policy should enable presidential candidates to free themselves of dependence on large contributions of those with special interests. Accordingly, it is essential to broaden the base of financial support for candidates and parties. To accomplish this, improvement of public understanding of campaign finance, coupled with a system of incentives for solicitation and giving, is necessary.

Letter from President John F. Kennedy to the President of the Senate and to the Speaker of the House Transmitting Bills to Carry out Recommendations of the Commission on Campaign Costs (May 29, 1962), in PUblic PAPERS OF THE PREsident of THE UNITED STATES: JOHN F. KENNEDY 1962, at 444 (1963) (emphasis added), available at http://www.presidency.ucsb.edu/site/docs/print_pppus.php?admin=035\&year=1962\& id $=219$. 
given cycle to at least $50 \%$ of the voting-age population. Second, contributions of $\$ 100$ or less should account for $75 \%$ of the money raised by average candidates, parties, and PACs. ${ }^{125}$ Reforms need not produce these results immediately, but should increase participation by smaller contributors in each election cycle in increments sufficient to reach the ultimate goals within a generation. Some may argue for lower or higher numerical goals; the targets could be adjusted based on further deliberation.

\section{B. One Proposal: Matching Funds and Tax Credits to Enhance Small Contributors' Influence}

The preceding discussion identified the problem of wealth's impact on democratic participation and provided a normative goal of campaign reform. This Part now turns from the abstract discussion of wealth and political participation to a practical proposal that is likely to move our political process toward the goal articulated above.

Lawmakers should provide incentives for a broader and more diverse group of Americans to make small contributions and enhance the effect of their participation by adopting matching funds and tax credits for contributions of $\$ 100$ or less.

The reform would provide a four-to-one match for contributions of $\$ 100$ or less. In other words, if a contributor gives $\$ 100$ to a candidate, the candidate would receive another $\$ 400$ in public funds, producing a total contribution worth $\$ 500$.

The second provision of the reform would make it easier for individuals to donate by providing a tax credit for smaller contributions. For example, a contributor who gives $\$ 100$ to a candidate would receive a tax credit that reduces her tax bill by $\$ 100$. The tax credit would be limited to $\$ 100$ per year (or $\$ 200$ for joint returns), refundable so that poorer families who do not pay taxes could use it, and well

${ }^{125}$ The percentage of a candidate's funds that comes from smaller contributions is a much more important number than average contribution size. For example, imagine Candidate A collects seventy-five $\$ 10$ contributions and twenty-five $\$ 2000$ contributions, and Candidate B collects five hundred $\$ 100$ contributions. They both have an average contribution size of $\$ 100$ and they both raise about the same amount (Candidate A has $\$ 50,750$ and Candidate B has $\$ 50,000)$. Nonetheless, the two candidates rely on different types of contributors for the bulk of their funds. Candidate A has raised $99 \%$ of his funds from $\$ 2000$ contributors, whereas Candidate B raised $100 \%$ of his funds from $\$ 100$ contributors. Note also that Candidate A has a contributor pool of only 100 people, whereas Candidate B has engaged 500 people. 
publicized to ensure that its use would not be limited to those who can afford attentive accountants.

Congress should adopt such a system for contributions to all federal parties, PACs, and presidential and congressional candidates when it considers revising the federal presidential funding system. ${ }^{126}$ States and localities should adopt such plans, either through the legislative process or via ballot initiative, for contributions to state and local parties, PACs, and candidates for state and local executive, legislative, and judicial offices.

\section{The Combination of Technology and Law Enhances Participation}

Matching funds and tax credits for smaller contributions, combined with emerging technology, would provide incentives for a broader and more diverse group of Americans to participate in political campaigns and would enhance the effect of their participation.

Under my proposal, matching funds will self-evidently multiply the importance of smaller contributors fivefold. Under the current system, many candidates think they can most efficiently raise large sums by appealing to larger contributors. By increasing the value of a $\$ 100$ contribution to $\$ 500$, the matching fund system increases the gain candidates realize by reaching out to smaller contributors.

A more difficult empirical question is whether the tax credit will prompt more people to give small contributions. Only about $5 \%$ of taxpayers used the $50 \%$ federal tax credit for political contributions before it was eliminated in $1986 .^{127}$

${ }^{126}$ In the 2004 presidential primary, Republican George W. Bush and Democratic presidential candidates Howard Dean and John Kerry rejected public funding, claiming that they did not want to be subject to the $\$ 45$ million spending limitation required as a condition to accept $\$ 19$ million in matching public funds. See Glen Justice, Kerry Lends Campaign $\$ 850,000$ and Plans More, N.Y. TIMES, Dec. 19, 2003, at A36 (explaining that Kerry followed Dean and Bush in opting out of taxpayer financing for the primary season). The Presidential Funding Act was introduced in Congress to update the presidential public funding system for the 2008 election. The bill encourages more candidates to accept public funding by increasing the amount participating candidates can spend from $\$ 45$ million up to $\$ 75$ million. S. 1913, 108th Cong. $\$ 4$ (2003). The bill also gives four-to-one matching funds on the first $\$ 250$ of a contribution to a participating candidate. S. 1913, 108th Cong. $\$ 2$ (2003). A proposed amendment to this provision, which would give candidates a four-to-one match only on contributions of $\$ 100$ or less, is discussed infra Part III.B.2.

${ }^{127}$ See David Rosenberg, Broadening the Base: The Case for a New Federal Tax Credit for Political Contributions 8 (2002) (unpublished white paper, on file with author) (showing that the average use of federal tax credit was $4.9 \%$ for 1980 to 1986). 
Several factors, however, suggest that the proposed full tax credit, when combined with other measures, will stimulate broader participation. The full tax credit provides more incentive to participate than the $50 \%$ federal tax credit. Extending the tax credit and matching funds to contributions to PACs and parties gives these entities an incentive to promote the plan and develop a permanent base of small donors. ${ }^{128}$ Further, the accompanying matching funds increase the impact of small contributions, which would boost the incentive of smaller contributors to give. Finally, emerging technology makes participation by smaller contributors easier than ever.

Politicians realized the potential of Internet fundraising when John McCain collected $\$ 5.6$ million online in the month following his surprise win in the 2000 New Hampshire Republican primary. ${ }^{129}$ By 2004, Democratic presidential candidate Howard Dean claimed to have raised half of his funds online, ${ }^{130}$ and $59 \%$ of Dean's campaign funds from individual contributions came from contributions of less than $\$ 200 .^{131}$ Due in part to increased Internet giving, contributions

Other writings that discuss the potential of broadening political participation through tax credits for contributions include JoHn M. DE FigUEIREdo \& ElizABETH GARRETT, PAYING FOR POlitics (Univ. of S. Cal. L. \& Econ. Research Paper No. 04-19, 2004), available at http://ssrn.com/abstract=578304; Robert G. Boatright \& Michael J. Malbin, Campaign Fin. Inst., Political Contribution Tax Credits and Citizen Participation (2003) (unpublished manuscript, on file with author).

${ }^{128}$ Thomas Cmar, U.S. Pub. Interest Research Group, Toward a Small Donor Democracy: The Past and Future of Incentive Programs for Small Political Contributions 36, 38-39 (2004) (asserting that extending tax credits to contributions to PACs and political parties will increase participation from smaller donors), available at http://uspirg.org/ uspirg.asp?id2=14231\&id3=uspirg\& (last accessed Oct. 8, 2004). Although my proposal is limited to matching funds and tax credits for small contributions to candidates, parties, and PACs, a strong argument exists for extending these devices to contributions to 501(c) (4) advocacy organizations and ballot question campaigns. Internal Revenue Code $\$ 501$ (c) (4) provides for exemption from federal income tax of civic leagues or organizations not organized for profit but operated exclusively for the promotion of social welfare. See RAYMond Chick \& Amy Henchey, Political Organizations And IRC 501(C) (4), at 1 (discussing exemptions for social welfare organizations), available at http://www.irs.gov/pub/irs-tege/eotopicm95.pdf (last visited Sept. 13, 2004). Extending these devices would offset the impact of wealth on the ability of the less wealthy to participate in public debate generally.

${ }^{129}$ See Jeff Glasser \& Betsy Streisand, Virtual Campaign Pays Off, U.S. News \& WORLD REP., Mar. 6, 2000, at 22, 22 ("McCain's Web appeal by the end of last week had raised a mighty $\$ 5.6$ million, about a quarter of his total take.").

${ }^{130}$ See Jon Sawyer, Dean's Savvy Web Pros Are Changing Political Campaigns, ST. LOUIS POST-DisPATCH, Jan. 11, 2004, at E3 (indicating that Internet fundraising "has accounted for fully half of the $\$ 40$ million Dean has raised").

${ }^{131}$ Campaign Fin. Inst., supra note 9, at tbl.3 (indicating sizes of contributions given to presidential candidates). 
of less than $\$ 200$ increased from $25 \%$ of funds from individuals raised by all presidential candidates in 2000 to $34 \%$ in $2004 .{ }^{132}$ Unlike raising money through channels such as telemarketing and direct mail, which can cost fifty cents for every dollar raised, advocates estimate that Internet fundraising costs as little as ten to twenty cents per dollar raised. ${ }^{133}$

While the Internet is an important tool, technology alone is an insufficient instrument for broadening participation from a diverse cross-section of Americans. First, Internet use and access varies across comunities. Internet users control more financial resources than other Americans. ${ }^{134}$ Currently, nearly one-quarter of Americans remain "offline." ${ }^{135}$ Further, the impact of disparities in wealth and the democratic value of widespread political participation are of such significance that we should not wait passively to see whether the Internet alone will eventually stimulate financial participation from a majority of voting-age Americans and shift the bulk of candidate funding from the donor class to contributors of $\$ 100$ or less. Thus, while the Internet sets the stage for the successful implementation of matching funds and tax credits, legal tools should not be abandoned as part of a comprehensive strategy to broaden and diversify participation in campaign funding by smaller contributors.

\section{Line Drawing and Value Judgments}

Several regulatory details affect the probability that a reform will enhance the influence of the less wealthy. These are ultimately linedrawing questions that involve balancing values such as fairness, administrability, and cost. The goal of this Subpart is not to resolve these disputes but to identify some of the most pressing issues that will arise in policy deliberations. While the answers to these questions

132 Id.

133 See Aravind Adiga, Net Lifts Campaign Finance Stakes, Fin. TIMES, July 4, 2000, at 5.

134 See David Guzman, Against All Odds, CIO MAG., May 1, 2004, at 45-46 ("In fall 2000, the Department of Commerce published statistics that showed that about 78 percent of households with annual incomes of $\$ 75,000$ or more had access to the Internet, while only 13 percent of households with annual incomes of $\$ 15,000$ or less had access."), available at 2004 WL 67900294.

135 See Amanda Lenhart, Pew Internet \& Am. Life Project, The Ever Shifting INTERNET POPULATION: A NEW LOOK AT INTERNET ACCESS AND THE DigITAL DIVIDE 3 (2003) ("Some $24 \%$ of Americans are truly offline; they have no direct or indirect experience with the Internet."), available at http://www.pewtrusts.com/pdf/ vf_pew_internet_shifting_pop.pdf (last visited Sept. 13, 2004). 
carry important implications, ${ }^{136}$ adoption of any of the perspectives discussed in this Subpart would likely result in a campaign finance system that more effectively promotes participation than does the status quo.

The first issue involves the size of contributions that qualify for matching funds and the amount of the match. The Presidential Funding Act, introduced in Congress in 2003 to update the presidential public funding system for the 2008 election, gives four-to-one matching funds for the first $\$ 250$ of a contribution (a "first- $\$ 250$ match"). ${ }^{137}$ Proponents of amending the bill argue that Congress should abandon the four-to-one match on the first $\$ 250$ of a contribution and instead give candidates a four-to-one match only on contributions of $\$ 100$ or less (a “\$100-or-less match"). ${ }^{138}$ The $\$ 100$-or-less match would deny matching funds when any individual's contributions exceed $\$ 100$. Thus, the $\$ 250$ and $\$ 100$ matches differ in both amount and structure. A $\$ 1000$ contribution disqualifies the donor for the $\$ 100$ match, while the $\$ 250$ match would still apply to the first $\$ 250$ and make the donor's contribution worth $\$ 2000$ to the candidate.

Proponents of the first- $\$ 250$ match might argue that by giving a larger match on all contributions, candidates would receive more public funds quickly and spend less time fundraising. The law should not discriminate against larger contributors simply because they donate more, one might argue, and the $\$ 100$-or-less match discourages individuals from giving between $\$ 101$ and $\$ 500$ (as doing so would disqualify their candidate from receiving the additional $\$ 400$ in public funds). A $\$ 100$-or-less match thus infringes on the expressive interests of those who want to show greater intensity in supporting their particular candidate. The $\$ 100$-or-less match also poses administrative difficulties: regulators would have to track and disqualify from matching funds those $\$ 100$ contributions by individuals who gave

${ }^{136}$ See Cmar, supra note 128, at 5 ("A careful study of experience at both the state and federal levels reveals that the structure of a contribution incentive program plays a significant role in determining its success.”).

137 See S. 1913, 108th Cong. $§ 2$ (2003) (providing four-to-one matching funds on the first $\$ 250$ of a contribution to a presidential candidate). Note that the Presidential Funding Act provides matching funds for presidential primaries. This Article proposes that matching funds and tax credits be expanded to apply to small contributions given to all federal candidates, parties, and PACs in primary and general elections, and that states and localities, either through the legislative or initiative processes, adopt similar reforms for state and local campaigns.

${ }^{138}$ See Spencer Overton, Editorial, Campaign Reform's Next Step, BosTOn GLOBE, Dec. 12, 2003, at A35 ("[W]e should not give a public subsidy to contributions over $\$ 100 \ldots$.$) .$ 
separate contributions on other occasions such that their aggregate gift exceeded $\$ 100$. $^{139}$

Proponents of the $\$ 100$-or-less match might respond that a fourto-one match on the first $\$ 250$ of a contribution adds a $\$ 1000$ public subsidy to a $\$ 2000$ contribution, making it worth $\$ 3000$ to a candidate. Because many candidates presently think they can raise the most money by appealing to larger contributors, this public subsidy simply gives candidates more incentive to cater to the donor class. The objective of matching funds should be to increase the importance of the smaller contributor, and using taxpayer funds to subsidize $\$ 2000$ contributions is counterproductive because it diminishes the relative importance of smaller contributors. Although the $\$ 100$-or-less match discourages contributions of between $\$ 101$ and $\$ 500$, those interested in expressing greater support could encourage a friend to give $\$ 100$, thereby broadening participation and yielding another $\$ 500$ for the candidate. Finally, technology resolves administrative burdens by allowing the FEC to review electronically the list of donors and ensure it awards matching funds only for contributions by individuals who give no more than a total of $\$ 100 .^{140}$

Similar questions revolve around whether the tax credit should be limited to households with incomes under $\$ 100,000$. Some might argue that as a matter of fairness, both a wealthy person and a poor person should be entitled to claim the same tax credit for a $\$ 100$ contribution to a candidate. On the other hand, extending the tax credit to households earning more than $\$ 100,000$ increases the cost of the program without any significant benefit, assuming that such households do not need incentives to make small contributions. Indeed, households earning more than $\$ 100,000$ represented $37 \%$ of those that

${ }^{139}$ Without administrative oversight, the $\$ 100$-or-less match could be circumvented if an individual were to give twenty $\$ 100$ checks to a candidate. The same danger of circumvention, however, exists when a contributor gives eight $\$ 250$ contributions under either the current FEC review for one-to-one matching funds for the first $\$ 250$ of a contribution or the Presidential Funding Act's proposed four-to-one match on the first $\$ 250$ of a contribution.

${ }^{140}$ Proponents of the $\$ 100$-or-less match might favor regulations that require that, when a candidate electronically submits names of contributors to the Federal Election Commission on a monthly basis for disclosure purposes and to receive matching funds, the FEC perform a computer cross-check to ensure matching funds be awarded only for contributions by individuals who contributed less than $\$ 100$ that particular month or earlier months. The FEC would also subtract matching funds from a candidate who received matching funds earlier for a contributor whose aggregate contributions in the most recent month totaled over $\$ 100$. 
claimed a state tax credit for political contributions in Ohio in $1999 .{ }^{141}$

Another concern with tax credits is that poorer populations may be less willing to part with $\$ 100$ for several months until it is refunded through the tax credit. In response, one might explore refunding the amount contributed within a few weeks. ${ }^{142}$ Any such proposal that deviates from the normal tax cycle, however, would likely face concerns about administrability and fraud. ${ }^{143}$

\section{Politics, Entrenchment, and the Cost}

Matching funds and tax credits may be more politically feasible than other forms of public financing.

Both tax credits and matching funds have a proven track record and an existing administrative infrastructure. Six states currently provide tax credits for political contributions (Arizona, Arkansas, Minnesota, Ohio, Oregon, and Virginia), ${ }^{144}$ and a $50 \%$ federal tax credit was available from 1972 to $1986 .{ }^{145}$ The federal presidential primary system currently provides up to $\$ 250$ of matching funds for the first $\$ 250$ of a contribution. ${ }^{146}$ The existing tax infrastructure and federal matching fund process could administer the programs in all federal elections.

While direct grants of equal amounts of public funding to candidates might be labeled "welfare for politicians" that suppress citizen participation until election-day voting, tax credits and matching funds allow citizens to shape the deliberative process by directly supporting

${ }^{141}$ See Rosenberg, supra note 127, at 13 (“[I]n Ohio claims by households earning more than $\$ 100,000$ per year rose from $25 \%$ of total claims in 1995 to $37 \%$ in 1999.”).

${ }^{142}$ See id. at 14 ("The Minnesota system gets money back into contributors' hands within six weeks-a strong incentive for citizens to 'loan' money to candidates and for candidates to seek those loans.").

${ }^{143}$ See id. ("As a simple, practical reality, creating a whole new system for refunding citizens' campaign contributions is fraught with the potential for fraud, delay, and misdirected funds and is probably too cumbersome to be introduced at the federal level. But following Minnesota's lead, some states may be able to implement an effective rapid refund loop.").

${ }^{144}$ See id. at 9 ("Today, six states provide some sort of tax credit for contributions to candidates, parties and/or PACs."); see also Cmar, supra note 128, at 19 (indicating that technically, "Minnesota takes a slightly different approach, operating a Political Contributions Refund ('PCR') program outside of its tax system”).

${ }^{145}$ See Rosenberg, supra note 127, at 7, 9 (showing federal tax incentives for 1972 through 2002).

${ }^{146}$ In the 2004 presidential primary, candidates who abided by $\$ 45$ million spending limits were entitled to up to $\$ 19$ million in matching public funds. See Justice, supra note 126, at A36. 
candidates they favor. These reforms also allow those without great wealth to use money to convey the intensity of their support. Further, unlike restrictions that can be said to drain money from get-out-thevote efforts and other political activity, matching funds and tax credits respect the fact that politics requires money and simply broadens the source of available funds.

Some might assert that a voucher system, such as the plan proposed by Yale Law School Professors Bruce Ackerman and Ian Ayres in Voting With Dollars, ${ }^{147}$ would better minimize the impact of disparities in wealth. ${ }^{148}$ Under Ayres and Ackerman's proposal, Congress would give every voter a special credit card or voucher worth $\$ 50$ that the voter could use to finance the campaigns of his or her favorite federal candidates. ${ }^{149}$ To prevent corruption, the authors propose that the identity of contributors remain anonymous. ${ }^{150}$

While Voting With Dollars articulates important principles that are consistent with reducing the relevance of disparities in wealth, Ayres and Ackerman's proposal is less feasible than offering matching funds and tax credits. For example, anonymous donations would undermine the benefits of full disclosure. As explained above, matching funds and tax credit programs have enjoyed bipartisan support and have operated successfully in several states. ${ }^{151}$ Ayres and Ackerman's

${ }^{147}$ ACKERMAN \& AYRES, supra note 25 (outlining a proposal for reforming campaign finance to reflect some of the more democratic qualities of secret-ballot voting); see also Foley, supra note 14, at 1204 ("The Constitution of the United States should contain a principle, which I shall call 'equal-dollars-per-voter,' that would guarantee to each eligible voter equal financial resources for purposes of supporting or opposing any candidate or initiative on the ballot in any election held within the United States."); Hasen, supra note 14, at 20-27 (arguing for a voucher system of campaign finance reform).

148 See ACKERMAN \& AYRES, supra note 147, at 43 (rejecting matching fund systems because Americans "should not be required to sacrifice private goods" to support candidates financially, and asserting that "[o]nly by combining votes and Patriot dollars can citizens regain a semblance of popular sovereignty in today's world").

${ }^{149}$ See id. at 4, 182 (indicating that "separate subaccounts will potentially be associated with each Patriot card: $\$ 10$ for House elections, $\$ 15$ for senatorial elections; and $\$ 25$ for presidential elections").

${ }^{150} I d$. at 6 .

${ }^{151}$ Perhaps because of conservative opposition to taxes, organizations as diverse as the American Enterprise Institute and the Public Interest Research Group have supported a federal tax credit for financial contributions to federal campaigns. See Rosenberg, supra note 127, at 7-20 (identifying and discussing themes that emerge from states' experiences with tax credit programs); Press Release, Colo. Pub. Interest Research Group Student Chapters, Biggest Fundraisers Dominate Michigan Elections: PIRGIM Report Uncovers Big Money's Influence On Election Outcomes (Oct. 15, 2002) ("PIRGIM called for ... tax credits for small political contributions ... to level 
proposal lacks this track record. In short, matching contributions and tax credits merge the ideals of widespread participation with more pragmatic proposals.

Practical strategies for reform should also anticipate the concerns of incumbent politicians, whose support is needed to enact the reform. Antireformers favor market distribution with minimal legal intervention due to their distrust of incumbent officials. By setting contribution limits too low or manipulating reforms in some other manner, the argument goes, entrenchment-minded incumbents will prevent insurgents from raising enough money to mount effective challenges. ${ }^{152}$ Campaign finance systems that rely more heavily on status quo market distribution, however, also entrench incumbents and contribute to legislative inaction. Incumbents often receive more large contributions from the donor class than challengers do. ${ }^{153}$ Thus, reforms like public funding sometimes fail in the legislative arena because incumbents hesitate to relinquish the funding advantages they enjoy over challengers. ${ }^{154}$

Matching funds and tax credits differ from other reforms because, rather than shifting the balance between candidates, they empower less wealthy citizens. Certainly, many incumbents will assess their prospects for reelection under the program before supporting it. But the answer will not be as clear as it would be with equal public funding

the playing field for non-wealthy candidates and voters."), available at http://www. copirgstudents.org/cocampus.asp?id2=8235 (last visited Aug. 28, 2004).

Cf. Robert Bauer, When "the "Pols Make the Calls": McConnell's Theory of Judicial Deference in the Twilight of Buckley, 153 U. PA. L. REV. 5, 19-26 (2004) (asserting that deference to congressional judgment neglects the reality and history of officeholder self-interest); Charles J. Cooper \& Derek L. Shaffer, What Congress "Shall Make" the Court Will Take: How McConnell v. FEC Betrays the First Amendment in Upholding Incumbency Protection Under the Banner of "Campaign Finance Reform," 3 Election L. J. 223, 227-28 (2004) ("McConnell v. FEC bestows the Supreme Court's imprimatur upon the 'legislative judgment' of Congress ... despite an overwhelming record demonstrating that the intent and effect of Title II [of BCRA] are to protect incumbents against meaningful electoral challenge.").

${ }^{153}$ See Public Campaign, supra note 5 (indicating that in the 2000 election cycle Senate incumbents "raised, on average, nearly three times as much as their challengers did from donors of $\$ 1,000$ or more" and that House incumbents "raised more than twice as much from donors of $\$ 1,000$ or more as their challengers," and stating that "[h] ard money remained the dominant source of campaign funding in the 2000 election cycle outweighing party soft money by a ratio of 4.4 to 1 ").

${ }^{154}$ Cf. Jennifer Fenn, House Budget Wipes Out Funding for Clean Elections, Cuts Medicare, LOWELL SUN (Mass.), May 17, 2002 ("The House approved a $\$ 22.8$ billion budget yesterday that wipes out funding for the voter-approved campaign-finance law and spends the money on state union contracts, a move seen by critics as a snub to voters and to the state's highest court."). 
for challengers and incumbents. Further, incumbents may enhance the quality of their professional and personal lives by spending less time outside of their districts soliciting large contributions from the donor class and more time at home with constituents, whose smaller contributions are multiplied in value.

The cost of matching funds and tax credits is also reasonable, especially in view of the need to ensure fair representation of all citizens in deliberations regarding hundreds of billions of dollars in tax revenues and government expenditures. Total spending by federal candidates and political parties was $\$ 2.8$ billion in the 2000 election cycle and $\$ 2.1$ billion in the 2002 election cycle. ${ }^{155}$

In light of past spending and the presence of private funds in a matching fund and tax credit system, a federal allocation of $\$ 3$ billion every other year (or about $\$ 13$ per voting-age resident of the United States) should more than cover the cost of a matching fund and tax credit system based on private contributions. ${ }^{156}$ By comparison, the U.S. Senate approved a 2005 budget that provides $\$ 421$ billion in de-

${ }^{155}$ These numbers are based on total disbursements by major and minor federal parties and congressional candidates of major and minor parties in the 2000 and 2002 election cycles. See The Big Picture, 2000 Cycle, The Price of Admission, Ctr. for Responsive Politics (n.d.), at http://www.opensecrets.org/bigpicture/stats.asp?cycle=2000\&type= A\&display=T (last visited Sept. 15, 2004) (showing campaign spending for congressional elections in 2000); News Release, Fed. Election Comm'n, Party Committees Raise More than $\$ 1$ Billion in 2001-2002 (Mar. 20, 2003) (indicating total federal and nonfederal disbursements by major federal party committees in 2002 election cycle), available at http://www.fec.gov/press/press2003/20030320party/20030103party.html; News Release, Fed. Election Comm'n, FEC Reports Increase in Party Fundraising for 2000 (May 15, 2001), available at http://www.fec.gov/press/press2001/051501 partyfund/051501partyfund.html (indicating total federal and nonfederal disbursements by major federal party committees in 2000 election cycle); E-mail from Sheila Krumholz, Research Director, Center for Responsive Politics, to Spencer Overton, Associate Professor of Law, The George Washington University Law School (June 28, 2004, 13:12:07 EST) (on file with the author) (indicating total spending for minor parties in 2000 and 2002 election cycles and spending for all presidential candidates in 2000 election cycle).

${ }^{156}$ If we reached the goal of $50 \%$ of voting-age residents of the United States making a small contribution, and if these contributions were all $\$ 100$ and received a $\$ 100$ tax credit and a $\$ 400$ match for the candidate (a total of $\$ 500$ ), the cost would be about $\$ 55$ billion per election. In light of the significance of this amount and the fact that the primary objective is to spark broader participation and increase the proportion of funds raised from smaller contributors, Congress might decide to limit the public funds to $\$ 3.0$ billion per election cycle (in 2004 dollars) and reduce incentives as the percentage of participation by smaller contributors increases (e.g., as participation increases, drop the match from four-to-one down to three-to-one, etc.). In the alternative, Congress might simply provide the public subsidy to the first $\$ 3.0$ billion in small contributions to be collected by candidates, parties, and PACs. 
fense spending, \$15.6 billion for NASA, \$29.2 billion for natural resources and the environment, $\$ 13.3$ billion for the No Child Left Behind Act, $\$ 30.5$ billion in discretionary spending, and tax cuts of $\$ 144$ billion between 2005 and 2009. ${ }^{157}$

To avoid the possibility that a future group of politicians would cut tax credits and matching funds to suppress citizen participation, ${ }^{158}$ Congress could alternatively make a one-time allocation to establish a $\$ 63$ billion trust that invests its funds in a low-risk vehicle. Such a trust would fund federal tax credits and matching funds for several hundred years and perhaps in perpetuity. ${ }^{159}$

Granted, tax credits and matching funds will not offset all of the problems that disparities in wealth cause. Just as people who lack resources are less likely to vote, ${ }^{160}$ a disproportionately high percentage of lower-income people will likely fail to contribute. Poorer people will be less able to part with $\$ 100$ until it is refunded in the form of a tax credit, and wealthier Americans will likely continue to be overrepresented even among those who give smaller contributions. ${ }^{161}$ As a result, many reformers who agree that disparities in wealth unfairly affect democratic participation may press for more dramatic reforms. Nevertheless, while matching funds and tax credits will not solve all

${ }^{157}$ For the Record, WASH. POST, Mar. 18, 2004, at T13. An annual expense of $\$ 1.5$ billion to support citizen political participation through matching funds and tax credits is also reasonable relative to the almost $\$ 40$ billion in tax credits awarded every year to subsidize other activities. See Individual Income Tax Returns: Selected Income and Tax Items for Specified Tax Years, 1985-2002, Internal Revenue Serv. (2004), at http://www. irs.gov/pub/irs-soi/02in01si.xls (last visited August 28, 2004) (indicating that American taxpayers claimed tax credits of $\$ 37.7$ billion, $\$ 45.6$ billion, and $\$ 38.9$ billion in 2000, 2001, and 2002 respectively).

${ }^{158}$ Congress repealed the $50 \%$ federal tax credit in the comprehensive tax reform package of 1986. See Rosenberg, supra note 127, at 7 ("[I]n the sprit of Reagan-era 'tax simplification,' the federal tax credit for political contributions was repealed in the comprehensive tax reform package of 1986."). Of course, some would argue that Congress did not do this to entrench itself, but to simplify the tax code.

${ }^{59}$ This estimate is based upon assumptions of a tax-free average annual return of $6 \%$ on a thirty-year U.S. Treasury bond, an average annual inflation rate of $3.5 \%$, and a program cost of $\$ 3.0$ billion (in 2004 dollars) every other year.

${ }^{160}$ See American Political SCIEnCE ASSOCiation, AMERICAN DEMOCRACy IN AN AGE OF RISING INEQUALITY 6 (2004) ("Nearly nine out of 10 individuals in families with incomes over $\$ 75,000$ reported voting in presidential elections while only half of those in families with incomes under $\$ 15,000$ reported voting."), available at http://www. apsanet.org/Inequality/taskforcereport.pdf.

${ }^{161}$ Although households with incomes of at least $\$ 100,000$ represented only about $13.4 \%$ of the U.S. population in 2000, they accounted for $26.5 \%$ of contributions of $\$ 100$ or less. DeNAvas-Walt ET AL., supra note 11, at 22; Wilcox July 3, 2004 Chart, supra note 10. 
problems, ${ }^{162}$ they represent an important first step toward using tested legal tools to broaden participation beyond the donor class.

\section{CONCLUSION}

The Supreme Court's recent decision in McConnell v. FEC signaled that the political branches serve an important function in structuring the role of money in democracy. Although some would prefer to ignore disparities in wealth, the true problem of campaign finance is that massive disparities in wealth cause disparities in citizen participation. A relatively small and wealthy donor class provides the bulk of funding for American politics and determines which candidates will run viable campaigns. Reforms such as matching funds and tax credits for smaller contributions would broaden participation, increase the importance of the smaller contributors, and lessen the impact of disparities in wealth on political participation.

${ }^{162}$ Demographic information on contributors to presidential primary candidates in the 2000 election cycle suggests that reforms that empower smaller contributors are more likely to result in economic diversification of contributors compared to gender, age, racial, and educational attainment diversification. Households with incomes under $\$ 100,000$ accounted for a much larger percentage of $\$ 100$-or-less contributions $(73.5 \%)$ than contributions over $\$ 200(14.4 \%)$. In contrast, women, people under 50 , people without a college degree, and people of color were grossly underrepresented not only among contributors of amounts over $\$ 200$, but also among contributors of $\$ 100$ or less. For example, although individuals without a college degree made up $74 \%$ of adults ages twenty-five or older in the United States in 2000, they accounted for only $15.7 \%$ of contributions over $\$ 200$ and $23.9 \%$ of contributions under $\$ 100$. U.S. Bureau of the Census, Educational Attainment in the United States: March 2000, at 1 (2000), available at http://www.census.gov/population/socdemo/education/ p20-536/p20-536.pdf; Wilcox July 3, 2004 Chart, supra note 10. It is unclear whether the underrepresentation among contributors of $\$ 100$ s or less is caused by: apathy or feelings of futility; the digital divide; candidate and party targeting of older educated white males in fundraising; older educated white males who serve as the primary organizers of fundraisers for candidates and tap into fairly homogenous social networks; a greater willingness of educated white males to make contributions to find favor with superiors at work; or a combination of these and other factors. While reforms that empower smaller contributors may prompt women and other underrepresented individuals to realize the importance of their financial gifts and stimulate giving, the extent of such an impact is uncertain. Nevertheless, women, younger Americans, people of color, and individuals without a college degree are less likely to control significant financial resources, and reforms that remove economic barriers carry an important expressive benefit of opportunity and inclusion. 